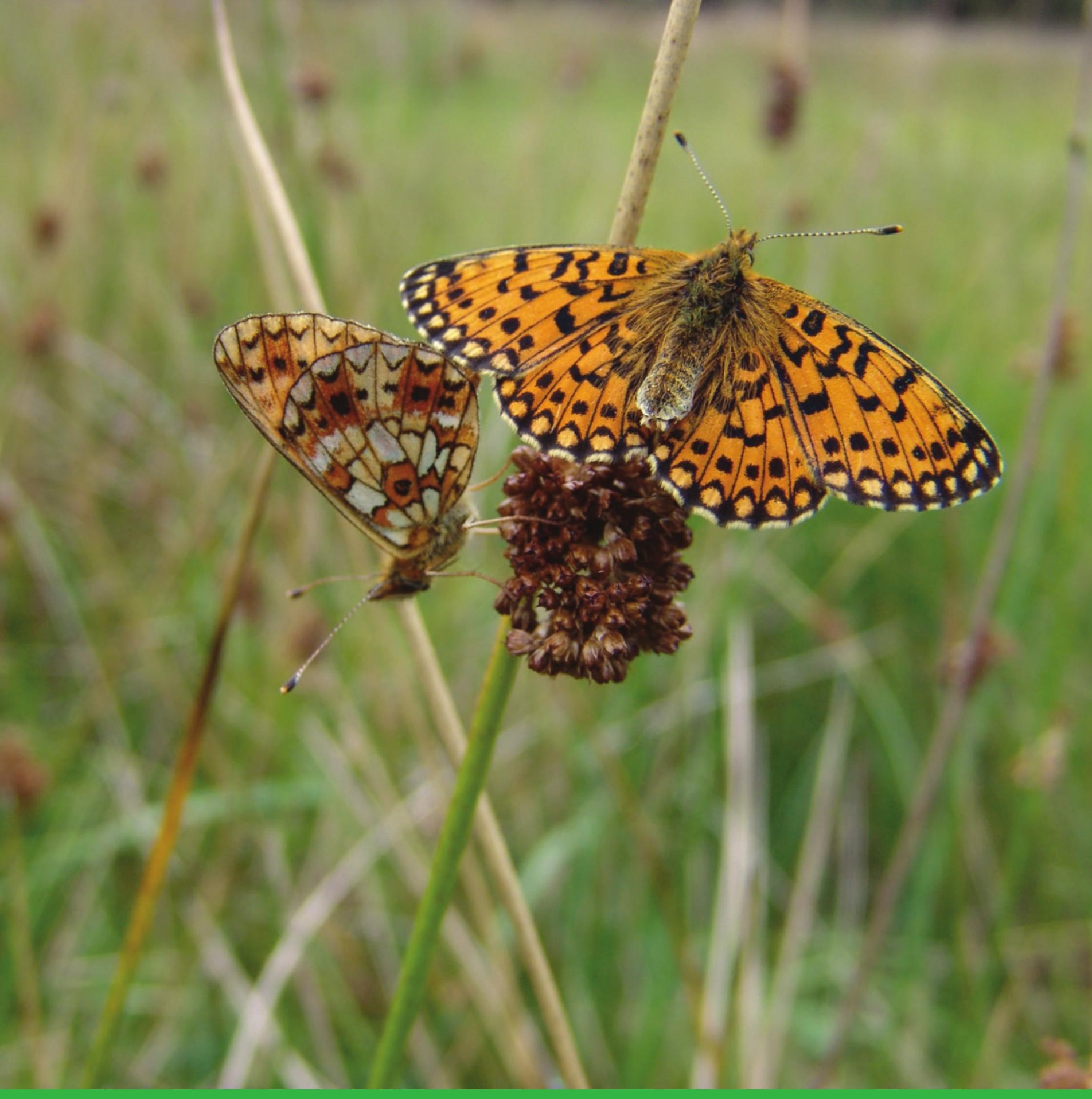

Verkenning indicatoren voor de beoordeling van terrestrische natuurkwaliteit op provinciaal schaalniveau 



\section{Verkenning indicatoren voor de beoordeling van terrestrische natuurkwaliteit op provinciaal schaalniveau}

J.G.M. van der Greft-van Rossum, F.F. van der Zee, B. de Knegt en R. Pouwels

Dit project is uitgevoerd door Wageningen Environmental Research (Alterra) in opdracht van en gefinancierd door het ministerie van Economische Zaken, in het kader van het Beleidsondersteunend onderzoekthema 'Biodiversiteit terrestrisch' (projectnummer BO-11-011.01-081).

Wageningen Environmental Research

Wageningen, oktober 2016

Rapport 2750

ISSN 1566-7197 
Greft-van Rossum, J.G.M. van der, F.F. van der Zee, B. de Knegt en R. Pouwels, 2016. Verkenning indicatoren voor de beoordeling van terrestrische natuurkwaliteit op provinciaal schaalniveau.

Wageningen, Wageningen Environmental Research, Rapport 2750. 28 blz.; 2 fig.; 0 tab.; 11 ref.

Provincies in Nederland zijn na de decentralisatie meer verantwoordelijk voor de natuurkwaliteit in de provincies. Om de outcome van het natuurbeleid te kunnen monitoren en hierover de Provinciale Staten te kunnen informeren, hebben provincies behoefte aan indicatoren die de kwaliteit van de natuur in de provincie weergeven. De afgelopen jaren is deze kwaliteit in Nederland op verschillende wijzen beoordeeld. Ook zijn enkele provincies gestart met het ontwikkelen van provinciale indicatoren. Het is echter onbekend of alle provincies dezelfde indicatoren willen gebruiken en in hoeverre deze samenhangen met indicatoren op landelijk schaalniveau. In dit project wordt een overzicht gegeven van indicatoren voor de terrestrische natuur en op basis van enkele schema's wordt de samenhang van de indicatoren weergegeven. Deze schema's geven inzicht waar provinciale indicatoren mogelijk goed aansluiten bij nationale indicatoren en waar eventuele knelpunten liggen voor een uitwerking op provinciaal niveau. Aandachtspunt daarbij is optimaal gebruik van monitoringssystemen. Naast de indicatoren die momenteel gebruikt worden, is er behoefte aan indicatoren voor het agrarisch gebied en het stedelijk gebied.

Trefwoorden: beoordeling, indicator, natuurkwaliteit, natuurnetwerk, NNN, provincies

Dit rapport is gratis te downloaden van http://dx.doi.org/10.18174/392987 of op

www.wur.nl/environmental-research (ga naar 'Wageningen Environmental Research' in de grijze balk onderaan). Wageningen Environmental Research verstrekt geen gedrukte exemplaren van rapporten.

2016 Wageningen Environmental Research (instituut binnen de rechtspersoon Stichting Wageningen Research), Postbus 47, 6700 AA Wageningen, T 03174807 00, E info.alterra@wur.nl, www.wur.nl/environmental-research. Wageningen Environmental Research is onderdeel van Wageningen University \& Research.

- Overname, verveelvoudiging of openbaarmaking van deze uitgave is toegestaan mits met duidelijke bronvermelding.

- Overname, verveelvoudiging of openbaarmaking is niet toegestaan voor commerciële doeleinden en/of geldelijk gewin.

- Overname, verveelvoudiging of openbaarmaking is niet toegestaan voor die gedeelten van deze uitgave waarvan duidelijk is dat de auteursrechten liggen bij derden en/of zijn voorbehouden.

Wageningen Environmental Research aanvaardt geen aansprakelijkheid voor eventuele schade voortvloeiend uit het gebruik van de resultaten van dit onderzoek of de toepassing van de adviezen.

Wageningen Environmental Research Rapport 2750 | ISSN 1566-7197

Foto omslag: Zilveren maan, foto Ruut Wegman (Wageningen UR) 


\section{Inhoud}

1

Inleiding $\quad \mathbf{5}$

1.1 Aanleiding 5

1.2 Probleemstelling en doel $\quad 5$

$\begin{array}{lll}1.3 \text { Aanpak } & 5\end{array}$

$\begin{array}{lll}2 & \text { Overzicht indicatoren } & 7\end{array}$

2.1 Gebruikte indicatoren op nationaal schaalniveau $\quad 7$



2.1.2 Indicatoren Ecosystemen $\quad 8$

2.1.3 Indicatoren Condities en Knelpunten 9

2.2 Huidige provinciale indicatoren 9

2.3 Gewenste indicatoren $\quad 11$

2.3.1 Beleidsdoel \& type indicator $\quad 12$

2.3.2 Indicatoren inhoudelijk $\quad 13$

2.3.3 Databehoefte 14

3

$\begin{array}{lr}\text { Samenhang indicatoren } & 16\end{array}$

3.1 Relatie indicatoren en beleidsdoelen 16

$\begin{array}{lll}3.2 & \text { Relatie indicatoren en monitoring } & 17\end{array}$

$\begin{array}{lll}3.3 & \text { Complementariteit in indicatorresultaten } & 17\end{array}$

4

$\begin{array}{ll}\text { Conclusies en aandachtspunten } & 18\end{array}$

$\begin{array}{ll}\text { Literatuur } & \mathbf{2 1}\end{array}$

$\begin{array}{lll}\text { Bijlage } 1 & \text { Overzicht indicatoren } & 22\end{array}$

Bijlage 2 Lijst van geïnterviewden $\quad 26$

$\begin{array}{lll}\text { Bijlage } 3 & \text { Lijst van afkortingen } & 27\end{array}$ 



\section{$1 \quad$ Inleiding}

\section{$1.1 \quad$ Aanleiding}

Provincies in Nederland zijn na de decentralisatie van het natuurbeleid in 2014 meer verantwoordelijk voor de natuurkwaliteit in de provincies. Om de outcome van het natuurbeleid te kunnen monitoren en hierover de Provinciale Staten en het rijk te kunnen informeren, hebben provincies behoefte aan indicatoren die de kwaliteit van de natuur in de provincie weergeven.

Op landelijk niveau zijn in Nederland de afgelopen jaren diverse indicatoren ontwikkeld om de kwaliteit van de natuur in Nederland weer te geven. De diverse indicatoren verschillen van elkaar op een aantal vlakken. De belangrijkste verschillen zijn het beleidsdoel waaraan ze bijdragen, het onderdeel van de natuur dat beoordeeld wordt en het schaalniveau waarop gekeken wordt. Elke indicator heeft daarmee specifieke uitgangspunten en werkt veelal met een daarop toegesneden monitoringsprogramma.

Op provinciaal niveau zijn enkele indicatoren ontwikkeld of in ontwikkeling. Deze sluiten vooralsnog aan bij de landelijk ontwikkelde indicatoren. Een aandachtspunt is dat de monitoring zoals opgezet voor de landelijke indicatoren vaak niet toereikend is voor de provinciale indicatoren; de informatiedichtheid blijkt dan te gering. Aanvullende data uit andere monitoringsprogramma's, zoals provinciale meetnetten, zijn in een aantal provincies beschikbaar. Het belangrijkste aandachtspunt bij het gebruik van indicatoren voor natuurkwaliteit is dat elke indicator een specifiek onderdeel van natuur beoordeelt en indicatorresultaten altijd moeten worden geïnterpreteerd in het licht van het doel waarvoor de indicator is ontwikkeld en de wijze waarop deze is samengesteld. Verschillende indicatoren met ogenschijnlijk verschillende resultaten kunnen allebei correct zijn ten opzichte van hun eigen doel. Het volledigste beeld van natuurkwaliteit wordt dan ook verkregen door de indicatoren in samenhang te bekijken; ze zijn vaak complementair aan elkaar.

Naast de ontwikkeling van indicatoren is in 2015 ook een nieuw monitorings- en evaluatiesysteem van start gegaan, getiteld Werkwijze Monitoring en Beoordeling Natuurnetwerk Nederland en Natura 2000 / PAS (WMBN, voorheen SNL), naast de al bestaande monitoringsprogramma's.

In het licht van de decentralisatie enerzijds en de ontwikkelingen op het gebied van indicatoren en monitoringsprogramma's anderzijds, is er behoefte om de samenhang tussen indicatoren in beeld te brengen. Deze samenhang is nodig om te voorkomen dat er een bestuurlijk afbreukrisico ontstaat als er op verschillende plaatsen verschillende uitspraken worden gedaan over dezelfde situatie.

\subsection{Probleemstelling en doel}

Door de verschuiving van de verantwoordelijkheden voor het natuurbeleid zullen provincies naast landelijke indicatoren ook provinciale indicatoren willen ontwikkelen om het provinciale natuurbeleid te kunnen evalueren. Enkele provincies zijn hier al mee gestart. De samenhang tussen de landelijke indicatoren onderling en tussen de landelijke en provinciale indicatoren zijn echter nog onduidelijk, net als de geschiktheid van monitoringssystemen voor de verschillende indicatoren. Ook is niet bekend of provincies dezelfde indicatoren willen gebruiken en in hoeverre deze samenhangen met indicatoren op landelijk schaalniveau.

Het doel van dit project is om 1) inzicht te geven in de mate van samenhang tussen indicatoren voor natuurkwaliteit op zowel landelijke als provinciale schaal en 2) de provinciale wensen voor aanvullende indicatoren weer te geven. De samenhang tussen indicatoren omvat onder meer hun beleidsdoel, de benodigde monitoringssystemen en complementariteit in beoordelingen. De provinciale wensen 
omvatten onder meer gewenste indicatoren, gewenste afstemming op landelijke indicatoren en aansluiting bij ontwikkelingen in andere provincies.

\subsection{Aanpak}

Om te komen tot aanbevelingen zijn vier kennisvragen opgesteld:

1. Welke (provinciale en landelijke) indicatoren worden gebruikt om natuurkwaliteit te beoordelen?

2. Welke wensen hebben provincies t.a.v. indicatoren voor natuurkwaliteit?

3. Zijn de beschikbare monitoringsgegevens geschikt om deze indicatoren ook per provincie toe te passen?

4. Hoe staat het met de samenhang tussen de indicatoren en complementariteit in beoordelingen?

De eerste kennisvraag is op basis van literatuurstudie uitgevoerd (o.a. Schmidt en Knegt, 2014). Hierbij is het begrip "natuurkwaliteit" ruim opgevat met de thema's soorten, ecosystemen en condities/knelpunten. Voor elke indicator is aangegeven voor welk doel (natuurbeleid) ze ontwikkeld zijn, welke monitoringsprogramma's de data leveren voor de indicator, op welk schaalniveau ze zijn uitgewerkt en welk type resultaat ze geven. Dit wordt besproken in paragraaf 2.1 en 2.2.

De tweede kennisvraag is op basis van interviews met een viertal provincies (Friesland, NoordHolland, Utrecht en Zuid-Holland, in overleg met BIJ12) uitgevoerd en wordt besproken in paragraaf 2.3.

Voor de derde kennisvraag is voor elk van de indicatoren aangegeven in hoeverre ze additionele gegevens nodig hebben voor een provinciale uitwerking. Dit is toegelicht in paragraaf 3.2.

Voor de vierde kennisvraag is op basis van het indicatoroverzicht een schema opgesteld waarin de samenhang van de indicatoren wordt weergegeven, zie paragraaf 3.1 en 3.3. Dit schema laat zien waar provinciale indicatoren mogelijk goed aansluiten bij gebieds- of nationale indicatoren en waar eventuele knelpunten liggen voor een uitwerking op provinciaal niveau. Daarnaast wordt de complementariteit van de indicatorresultaten besproken. 


\section{Overzicht indicatoren}

\subsection{Gebruikte indicatoren op nationaal schaalniveau}

De meeste indicatoren die gebruikt worden voor de beoordeling van de kwaliteit van natuur zijn uitgewerkt op nationaal schaalniveau. Deze indicatoren zijn onder te verdelen in drie hoofdthema's: soorten, ecosystemen en condities/knelpunten. Een deel van deze indicatoren is toegespitst op specifiek natuurbeleidsdoelen (biodiversiteitsdoelen), zoals de Vogel- of Habitatrichtlijn (instandhoudingsdoelen). Andere zijn ontwikkeld voor algemene evaluaties van de natuur of evaluaties in het kader van de NNN. De databehoefte van de indicatoren kan sterk verschillen in bijvoorbeeld ruimtelijke dekking en meetfrequentie. Figuur 1 geeft de relatie tussen data, indicator en beleidsdoel schematisch weer.

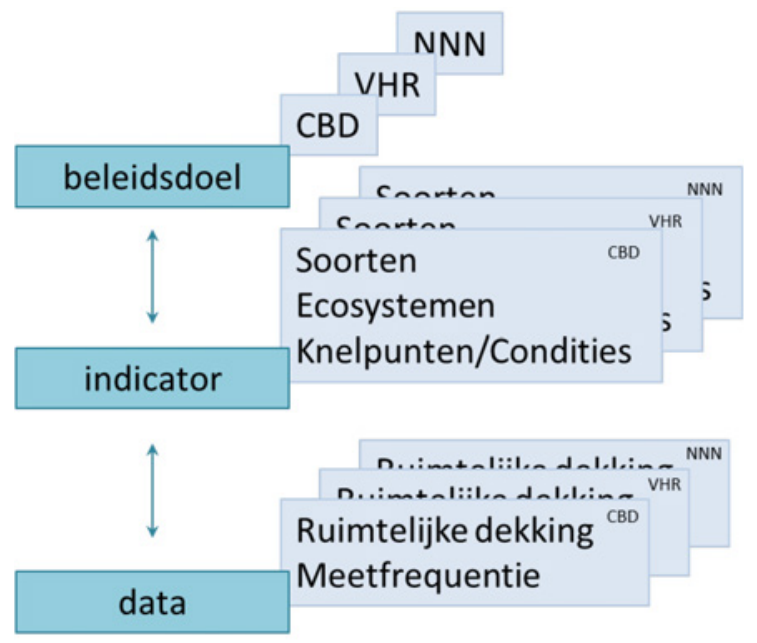

Figuur 1 Schematische weergave van de plek van indicatoren ten behoeve van verschillend natuurbeleid. Er is grote overlap tussen de verschillende indicatoren, maar er zijn ook verschillen met betrekking tot selecties van soorten/vegetatietypen, de ruimtelijke dekking en de meetfrequentie van gegevens ten behoeve van rapportages.

Hieronder worden de indicatoren per hoofdthema beschreven, waarbij de volgende punten aan bod komen: het doel (natuurbeleid) waarvoor ze ontwikkeld zijn, welke monitoringsprogramma's de data leveren voor de indicator, op welk schaalniveau ze zijn uitgewerkt en welk type resultaat ze geven. In bijlage 1 wordt een overzicht gegeven in tabelvorm, inclusief voorbeeldresultaten in grafiekvorm.

\subsubsection{Indicatoren voor soorten}

Indicatoren voor soorten geven uiteraard weer hoe het gaat met bepaalde soorten. Op landelijk niveau worden de volgende vier indicatoren gebruikt:

- RLI - Rode Lijst Indicator

- LPI - Living Planet Index

- SvI HR-soorten - Staat van Instandhouding Habitatrichtlijnsoorten

- SvI VR-soorten - Staat van Instandhouding Vogelrichtlijnsoorten 


\section{Overeenkomsten en verschillen}

De overeenkomst tussen deze indicatoren is dat ze alle vier een trend weergeven van bepaalde soorten. Deze trends zijn relatief, ten opzichte van een beginjaar of doel dat gekozen is op basis van databeschikbaarheid of beleidsrelevantie.

De verschillen tussen deze indicatoren zitten in het doel, het type resultaat, de gekozen soorten en de onderliggende monitoringsdata.

- Doel/beleid: de RLI en LPI dragen bij aan de internationale CBD, de SVI HR en VR aan de Europese VHR.

- Type resultaten: LPI geeft trends in soortverspreiding ten opzichte van het begin van het NEM, circa 1994. SvI houdt ook rekening met populatiegroottes. LPI als geheel maakt geen onderscheid in meer of minder gewenste stijging van soortverspreiding (veelal wordt stijging van een zeldzame soort als gewenst gezien en van een heel algemene of invasieve soort als minder gewenst; dit laatste kan immers een aanduiding zijn voor het niet optimaal functioneren van een ecosysteem). Daarentegen houdt de SVI rekening met het feit dat een populatiegrootte onder of boven het gestelde doel kan liggen. Ook wordt bij de bepaling van de SvI naast populatieomvang en verspreiding met andere aspecten rekening gehouden.

- Data en soorten: de RLI en LPI maken gebruik van de jaarlijkse monitoringdata van het NEM in combinatie met waarnemingen van de NDFF die bewerkt zijn met occupancy-modellen. De RLI omvat data voor zeven soortgroepen (zoogdieren, broedvogels, reptielen, amfibieën, dagvlinders, libellen en hogere planten); de LPI probeert zo veel mogelijk soorten weer te geven waarvoor data beschikbaar zijn. De SvI-soorten zijn gebaseerd op (maximaal) zesjaarlijkse inventarisaties van HRen VR-soorten.

NB De Rode Lijst Indicator in zijn huidige vorm is in 2015 door het CBS ontwikkeld. In voorgaande jaren is als maat de populatieomvang van de Rode Lijstsoorten gehanteerd; deze versie heeft het CBS laten vervallen.

\subsubsection{Indicatoren Ecosystemen}

Indicatoren voor ecosystemen geven weer hoe het staat met de natuurkwaliteit van ecosystemen. Hierin is op hoofdlijnen een tweedeling te maken: informatie die op landelijke schaal wordt geanalyseerd en informatie die zowel voor de gebieden zelf als op landelijk niveau wordt gebruikt. De eerste set wordt benoemd onder 'Indicatoren t.b.v. landelijke informatie'; de tweede set onder 'Indicatoren t.b.v. gebiedsinformatie, landelijk samen te vatten'.

\section{Indicatoren t.b.v. landelijke informatie}

- Natuurkwaliteit Ecosystemen Recente trends

- Natuurwaarde Ecosystemen (kwaliteit x areaal)

- Natuurwaardeontwikkeling (trend kwaliteit $x$ areaal)

- SvI Habitattypen

\section{Overeenkomsten en verschillen}

De overeenkomst tussen deze indicatoren is dat ze alle vier zowel een trend in ecosysteemkwaliteit als een actuele waarde ten opzichte van een gekozen referentie van ecosysteemkwaliteit weergeven. De trends zijn ten opzichte van verschillende jaren of situaties weer te geven; de absolute waarde wordt gerelateerd aan het doel van de indicator. Daarnaast geven ze alle informatie op landelijk niveau.

De verschillen tussen deze indicatoren zitten dan ook voornamelijk in het doel en het monitoringssysteem en daarnaast in de mogelijkheid van terugkoppelen naar gebiedsniveau.

- Doel/beleid: de indicatoren voor Natuurkwaliteit en Natuurwaarde (CBD) refereren alle drie aan intacte ecosystemen, waarbij Natuurkwaliteit zich richt op de kwaliteit van ecosystemen o.b.v. het voorkomen van kenmerkende soorten; de Natuurwaarde houdt hierbij ook rekening met het huidige areaal van de ecosystemen. De indicator SvI Habitattypen (VHR) geeft natuurkwaliteit als mate van instandhouding van habitattypen en wijziging hierin ten opzichte van een eerder meetmoment, op basis van biotische (soort-) en abiotische informatie. 
- Monitoringssysteem en terugkoppeling naar gebiedsniveau: Natuurkwaliteit en Natuurwaarde worden bepaald met behulp van jaarlijkse NEM-data van kenmerkende soorten van ecosystemen, afgezet tegen het niveau van deze soorten in een zo veel mogelijk intact ecosysteem. Het NEM is opgezet volgens een landelijke steekproef van monitoringslocaties. Dit betekent dat de informatie een goed landelijk beeld geeft. De resultaten van de monitoring geven geen volledig beeld per onderliggend gebied, omdat de steekproef daarvoor niet dicht genoeg is. De SvI Habitattypen wordt mede bepaald op basis van informatie uit de Standaard Data Formulieren (zie hieronder). Deze informatie is daarmee wel terug te herleiden naar de informatie van de afzonderlijke gebieden.

\section{Indicatoren t.b.v. gebiedsinformatie, landelijk samen te vatten}

Op gebiedsniveau gebruiken beheerders vaak meer gedetailleerde informatie om inzicht te krijgen in de specifieke situatie van integrale natuurgebieden, met als doel de effectiviteit van het beheer en maatregelen te evalueren. De belangrijkste indicatoren die momenteel op gebiedsniveau beschikbaar zijn, zijn indicatoren gebaseerd op de Standaard Data Forms (SDF) in de Natura2000-gebieden en de indicator natuurkwaliteitsbeoordeling NNN op basis van informatie die verzameld wordt in de WMBN. Hieronder valt ook in de indicator Habitattypekwaliteit N2000; deze is echter nog in ontwikkeling en is daarom niet aangegeven in het overzicht. De habitatkwaliteit wordt nu nog niet uniform bepaald; in de SDF wordt dit gebaseerd op structuur en functie, in de beheerplannen wordt dit gebaseerd op de vier poten in het profielendocument: vegetatie, abiotiek, typische soorten en structuurkenmerken. Vanuit het schaalniveau van gebieden zijn momenteel nog geen indicatoren doorontwikkeld voor het provinciaal schaalniveau. Wel is een eerste aanzet gemaakt om indicatoren vanuit de SDF om te zetten naar provinciaal schaalniveau (Bink et al. 2015).

- SDF - Standaard Data Formulieren

- Indicator NNN

\section{Overeenkomsten en verschillen}

De overeenkomst tussen deze indicatoren is dat ze beide de kwaliteit van een gebied weergeven met betrekking tot zowel flora/fauna als abiotische condities. Daarbij wordt beoordeeld in hoeverre een bepaald nagestreefd doel (Beheertype/Habitattype) wordt gehaald.

Bij de SDF worden daarbij de soorten apart beoordeeld, terwijl de soorten bij de NNN onderdeel zijn van de beoordeling van de Beheertypen. Een ander verschil is dat de SDF ook de potentie tot herstel meeneemt in de beoordeling. De NNN beoordeelt alleen de huidige situatie. Daarnaast vindt de beoordeling van de SDF plaats voor elk Natura2000-gebied afzonderlijk. De beoordeling van de NNN wordt ook op gebiedsniveau geaggregeerd, maar deze gebieden zijn grootschaliger.

Aangezien beide indicatoren zijn opgebouwd uit verschillende aspecten, is het ook mogelijk om deze aspecten apart weer te geven. In Bink et al. (2015) zijn hiervan enkele voorbeelden uitgewerkt.

\subsubsection{Indicatoren Condities en Knelpunten}

Naast de indicatoren die trend en status van soorten en ecosystemen weergeven, zijn er afgeleide indicatoren ontwikkeld die inzicht geven in de knelpunten op soort- en ecosysteemniveau. Het betreft twee indicatoren:

- Knelpunten Soorten

- Knelpunten Ecosystemen

\section{Overeenkomsten en verschillen}

De overeenkomst tussen deze indicatoren is dat beide zich op landelijke schaal richten op gebrek aan geschikt leefgebied, versnippering, verdroging en vermesting.

De verschillen tussen deze indicatoren liggen vooral in het doel en de data.

- Doel: de indicator Knelpunten Soorten geeft het percentage soorten aan dat last heeft van genoemde knelpunten ten opzichte van een goede situatie. De indicator Knelpunten Ecosystemen geeft aan welk percentage oppervlakte van ecosystemen last heeft van deze knelpunten ten opzichte van een niveau voor duurzame instandhouding van natuur. 
- Data: de soortindicator wordt gevoed met enerzijds oppervlakte-, gvg-, en stikstofbehoeften voor soorten en anderzijds actuele oppervlakte-, gvg- en stikstofcondities. Voor de bepaling van de knelpunten worden modellen of GIS-analyses gebruikt, waarbij de vereisten voor de optimale situatie naast de huidige situatie worden gezet en de verschillen hiertussen aangeven waar knelpunten liggen.

\subsection{Huidige provinciale indicatoren}

Provincies gebruiken al een aantal indicatoren voor natuurkwaliteit. Enkele provincies hebben zelf indicatoren ontwikkeld, deels op basis van hun eigen meetnet, terwijl andere provincies indicatoren hebben ontwikkeld op basis van enkele van de landelijke indicatoren genoemd in paragraaf 2.1. Voor een eerste inventarisatie van provinciale indicatoren zijn indicatoren van de provincies Friesland, Noord-Holland, Utrecht en Zuid-Holland in interviews verzameld.

\section{Provinciale indicatoren, provinciaal ontwikkeld}

Om de provinciale natuurontwikkelingen in beeld te brengen, heeft een aantal provincies zelf al indicatoren ontwikkeld. Veelal zijn deze samengesteld op basis van eigen meetnetten. Voorbeelden zijn:

a. Trend in natuurkwaliteit per biotoop (Utrecht). Kenmerken:

* provinciaal beleid: biotopen zoals bepaald in provinciaal natuurbeleidsplan in de jaren negentig;

* biotopen: natuurlijk, agrarisch en stedelijk, zowel binnen als buiten de EHS;

* frequentie van resultaten: grote tijdstap, nl. periode rond 1990 en rond 2010;

* monitoring: provinciaal meetnet, aangevuld met NEM- en NDFF-data, brede soortenset;

* monitoring en resultaten: zowel vlakdekkend als trendbepaling;

* vergelijking provincie met Nederland.

b. Biodiversiteit in beheertypen, SNL (Utrecht) Kenmerken:

* beleid en soortenset: aansluitend bij landelijk SNL;

* frequentie van resultaten: grote tijdstap, nl. 20 jaar;

* resultaat: beschrijvend, o.b.v. getalsanalyse;

c. Ontwikkeling bedreigde soorten (Utrecht). Kenmerken:

* soortenset: Oranje Lijst (provinciaal ontwikkelde lijst van bedreigde soorten o.b.v. dezelfde criteria als de Nederlandse Rode Lijst);

* resultaat: beschrijvend.

d. Soortenrijkdom ecosystemen (Utrecht). Kenmerken:

* bepaling: kwaliteitsbepaling ecosystemen o.b.v. aantal karakteristieke soorten van onderliggende biotopen, areaal gewogen, geaggregeerd naar ecosystemen graslanden, heide en open zand, bos, akkers, moerassen, water;

* frequentie van resultaten: vrij grote, wisselende tijdstappen: 1990-2010-2015.

e. Gebiedsschouw nieuwe natuurgebieden (Zuid-Holland). Kenmerken:

* Doel: ontwikkeling in nieuwe natuur volgen los van kwaliteit bestaande natuur (ontwikkeling op zichzelf bekijken en nog niet afmeten aan doelen van het voorgestelde natuurtype);

* Monitoring: beperkte inventarisatie, geen echte nulmeting; geeft wel meer inzicht dan WMBN in eventueel benodigd extra beheer;

* Resultaat: beeld ontwikkeling nieuwe natuur.

Kenmerken voor de provinciale ontwikkeling zijn:

- toegespitst op eigen informatiewens, daarnaast ook aangepast aan landelijke (NNN) ontwikkeling;

- provinciale monitoring;

- provinciedekkend, dus zowel NNN als VHR, N2000 en de gebieden daarbuiten;

- aandacht voor nieuwe natuur en nieuwe soorten;

- provinciale uitwerking bedreigde soorten (Oranje Lijst). 


\section{Provinciale indicatoren op basis van landelijke indicatoren}

De afgelopen jaren heeft ook een aantal provincies indicatoren ontwikkeld om de kwaliteit van de terrestrische natuur in de provincie te beoordelen. De meeste van deze indicatoren zijn afgeleid van bestaande landelijke indicatoren (CBS 2015; Knegt et al. 2012, 2013; Greft-van Rossum 2015). Deze groep bestaat uit provinciale uitwerkingen van:

- RLI - Rode Lijst Indicator (noot: niet de huidige versie) (zie paragraaf 2.1.1)

- LPI - Living Planet Index (zie paragraaf 2.1.1)

- Natuurkwaliteit Ecosystemen Recente trends (zie paragraaf 2.1.2)

- Natuurwaarde Ecosystemen (kwaliteit x areaal) (zie paragraaf 2.1.2)

- Natuurwaardeontwikkeling (trend kwaliteit $x$ areaal) (zie paragraaf 2.1.2)

- Knelpunten Soorten (zie paragraaf 2.1.3)

- Knelpunten Ecosystemen (zie paragraaf 2.1.3)

Voor verdere uitwerking van deze indicatoren lopen actuele ontwikkelingstrajecten: de uitwerking van LPI vindt plaats in een ontwikkelingstraject bij het CBS op verzoek van BIJ12; de uitwerking van Natuurkwaliteit Ecosystemen start bij Wageningen Environmental Research (Alterra)/PBL in overleg met enkele provincies.

\section{Databeschikbaarheid}

In het algemeen is bij de provinciale uitwerking van indicatoren het belangrijkste aandachtspunt de beschikbaarheid van voldoende soortdata. Landelijk wordt bij de Natuurwaarde-indicatoren gebruikgemaakt van het Netwerk Ecologische Monitoring (NEM) en bij de LPI wordt gebruikgemaakt van de NDFF-data die zowel de NEM-data bevatten als andere geprotocolleerde datasets (zoals SNLdata, Atlasdata, gerichte gebieds- en soortinventarisaties) en individuele waarnemingen. Het NEM is opgezet om op landelijk niveau soorten te monitoren en kan trends in soort-abundanties geven; de combinatie van NEM- en andere NDFF-data kan via occupancy-modelling trends in soortverspreiding geven.

In de praktijk blijkt voor provinciale uitwerking van de Natuurwaarde-indicatoren aanvullende monitoring noodzakelijk. Bij enkele provincies heeft de provinciale monitoring voldoende dekking en continuïteit om deze datasets aanvullend te gebruiken. Bij andere provincies zijn monitoringsinspanningen gaandeweg verminderd of gestopt, waardoor weliswaar oude datasets beschikbaar zijn, maar waarbij continuïteit ontbreekt. Hoewel deze sets geschikt kunnen zijn om het verloop in natuurkwaliteit op termijn van decennia weer te kunnen geven, blijken vaak aanvullende data nodig te zijn om trends op jaarbasis weer te kunnen geven.

Uitwerking van de LPI op provinciaal niveau vraagt aanvullende inspanningen in occupancy modelling op basis van de NDFF-datasets; het CBS werkt hieraan in opdracht van BIJ12.

\section{Indicatoraanpassingen}

Specifiek is voor de Rode Lijst Indicator vanaf 2015 nog geen provinciale versie gerealiseerd. Dit is wel gebeurd voor de oude RLI-versies; de berekening van deze indicator is echter stopgezet door het CBS vanwege een aantal methodologische kritiekpunten. Provinciale uitwerking van de huidige versie vraagt nog verdieping in de provinciale referenties: de Rode Lijst is landelijk vastgesteld; op welke wijze kan dan de mate van bedreiging van de soorten in een provincie weergegeven worden?

Specifiek voor de Natuurkwaliteit- en Natuurwaarde-indicatoren geldt dat de kwaliteit van ecosystemen gerelateerd wordt aan een intact ecosysteem, waarvoor landelijke referenties worden gebruikt t.a.v. abundanties van karakteristieke soorten in ecosystemen. Dergelijke referenties zijn nog niet provinciaal vastgesteld. In 2016 volgt een onderzoek naar mogelijkheden hierin.

Specifiek voor de Living Planet Index geldt dat de indicator met meer typen data gevuld kan worden dan de Natuurkwaliteit Ecosysteem-indicatoren, namelijk zowel abundantie- als verspreidingsdata uit het NDFF, zoals hierboven al beschreven. Enerzijds introduceert dit meer onzekerheid, anderzijds maakt dit het mogelijk om meer soorten en soortgroepen in de indicator mee te nemen. Tegelijkertijd betekent het ook dat de gehanteerde soortensets kunnen verschillen, zowel tussen provincies 
onderling als tussen provincies en Nederland. Dit vormt een aandachtspunt bij onderlinge vergelijkingen.

\subsection{Gewenste indicatoren}

In gesprekken met de vier eerder genoemde provincies hebben deze provincies een aantal wensen t.a.v. indicatoren en monitoring benoemd. Deze wensen zijn samengevat in de volgende onderwerpen: beleidsdoel \& type indicator; indicatoren inhoudelijk; monitoring; onderlinge vergelijking provincies/landelijk.

\subsubsection{Beleidsdoel \& type indicator}

\section{Provinciale toepassing}

Bij de meeste provincies loopt momenteel nog het proces om concrete doelen vast te stellen voor natuur en biodiversiteit, samenhangend met de verantwoordelijkheden voor natuur die met het decentralisatieproces naar de provincies zijn gegaan.

Afgelopen tijd zijn daarin in het kader van het Natuurpact stappen gezet: zo zijn voor rapportage van provincies aan het rijk afspraken gemaakt over de Voortgangsrapportage Natuur (VRN). Een van de onderdelen daarvan is dat de provincies de kwantiteit en de kwaliteit van de voortgang van het NNN rapporteren. Met de werkwijze MBN hebben de provincies samen met de TBO's concreet natuurkwaliteit geformuleerd. Verder zijn er in het kader van de PAS onderdeel natuur afspraken gemaakt over natuurkwaliteit.

Vanuit het Rijk is de Rode Lijst Index de enige indicator die in de rijksbegroting is meegenomen en juist deze is nog niet provinciaal uitgewerkt. Internationale verdragen zoals de CBD hebben geen expliciete indicatoren voorgeschreven, echter wel randvoorwaarden voor het beleid. De huidige keuze van indicatoren die voor CBD gebruikt wordt, is dus niet voorgeschreven vanuit het CBD.

De Voortgangsrapportage Natuur wordt door een provincie verwoord als een groeimodel; ze starten met het doorgeven van gegevens over verwerving en inrichting NNN aan het rijk, t.z.t. ook gevolgd door data over Natuurkwaliteit NNN en ander beleid. Vanaf 2016 start tevens de rapportage over de voortgang van het PAS-programma onderdeel natuur.

Een andere provincie vat de informatiebehoefte als volgt samen: de provincie wil graag kunnen informeren op hoog aggregatieniveau, gekoppeld aan diepgaander informatie.

Enkele provincies hebben wel overkoepelende doelen aangegeven. Een genoemd strategisch doel is het EU-biodiversiteitsdoel:

- De biodiversiteit neemt in 2020 niet verder af (soorten en gebieden).

De provincie wil hier in haar eigen beleid aandacht aan schenken.

Alle vier provincies geven daarnaast aan dat ze in elk geval voor de Staten een beeld van de natuurkwaliteit van de gehele provincie willen geven. Een provincie meldt hierin een onderverdeling: voor Gedeputeerde Staten: werken de instrumenten, leveren ze genoeg op; voor Provinciale Staten: zijn de doelen gehaald, op heel globaal ecosysteemniveau. Voor de uitvoering en evaluatie van het provinciale natuurbeleid zijn de provincies daarnaast geïnteresseerd in meer detailinformatie.

- Voor ecosysteemindicatoren betekent dit dat naast de natuurgebieden aanvullingen gewenst zijn voor andere gebieden (incl. grote wateren) (zie paragraaf 2.3.2).

- Voor soortindicatoren betekent dat de wens om soortinventarisaties provinciedekkend uit te voeren, ook als het bijvoorbeeld om Habitatrichtlijnsoorten gaat.

- Areaalmonitoring vindt daarnaast ook plaats.

Eén provincie geeft aan dat ze zou willen dat Nederland ook de indicatoren voor Natuurwaarde en Natuurkwaliteit Ecosystemen zou willen toepassen, ook op provinciaal niveau.

In het algemeen zijn de provincies wel geïnteresseerd in de provinciale resultaten van de indicatoren voor het beleid waarvoor Nederland internationaal verantwoordelijk is. 


\section{VHR N2000}

Alle vier provincies zijn geïnteresseerd in de VHR-indicatoren voor SvI VR- en HR-soorten en de SvI Habitattypen. Ook zijn alle vier provincies geïnteresseerd in de indicatoren voor N2000-gebieden o.b.v. de uitkomsten van de Standaard Data Formulieren. Een aandachtspunt betreft afstemming van monitoring en monitoringresultaten tussen provincies bij provinciegrens-overschrijdende gebieden: nu is één provincie de trekker voor het gehele gebied, terwijl de monitoring wordt uitgevoerd per provincie, dus voor een gebiedsdeel. De SDF wordt wel weer per geheel gebied gegeven, dus provinciegrens-overschrijdend.

\section{CBD}

Voor de indicatoren voor ecosystemen leeft bij de meeste provincies de wens om een dergelijke indicator elk jaar betrouwbaar te kunnen vaststellen. Eén provincie heeft geen behoefte aan het gebruik van een nieuwe indicator voor natuurkwaliteit en blijft graag de eigen methode gebruiken, tenzij de nieuwe indicator aantoonbaar gemakkelijker of goedkoper te bepalen is.

Ook willen provincies graag een provinciale Rode Lijst-indicator. In 2015 is de landelijke Rode Lijstindicator inhoudelijk gewijzigd; aandachtspunt hiervan is de uitwerking op provinciaal niveau. Zoals aangegeven in paragraaf 2.2 heeft één provincie al invulling gegeven aan een indicator over bedreigde soorten, namelijk met een zogenoemde Oranje Lijst. Eén provincie vraagt ook verduidelijking van de 1950-referentie: waren er toen geen bedreigde soorten? Een andere provincie geeft aan toch niet te sturen op RL-soorten, maar juist op karakteristieke soorten van het NNN.

\subsubsection{Indicatoren inhoudelijk}

\section{Ruimtelijke dekking: alle ecosysteemtypen}

Als grote inhoudelijke wens noemen alle vier provincies de mogelijkheid om de natuurkwaliteit voor de gehele provincie weer te kunnen geven, dus zowel voor alle natuurgebieden (binnen én buiten NNN/N2000) als voor agrarische en stedelijke gebieden; enkele provincies noemen ook recreatieterreinen en slootkanten. Eén provincie geeft aan dat de informatie voor NNN-gebieden op dezelfde wijze weergegeven mag worden als die voor Habitattypen. Voor de agrarische monitoring geven enkele provincies aan dat ze graag zien dat deze indicator gebaseerd wordt op meer dan alleen weidevogels; botanische data ontbreken. Eén provincie geeft aan dat er ook nooit consistent is gemonitord op flora in het agrarisch gebied.

Punt van aandacht hierbij is dat het stedelijk en agrarisch gebied sterk door de mens beïnvloede gebieden zijn, waarvoor geen natuurlijke referenties te bepalen zijn. De kwaliteit ten opzichte van een intact systeem zoals gebruikt voor natuurlijke ecosystemen in landelijke ecosysteemgraadmeters kan voor deze gebieden dan ook niet bepaald worden.

Qua ruimtelijke dekking leeft ook de wens om onderscheid te kunnen maken naar gebiedsbeleid: in of buiten de NNN, wel of niet VHR- of N2000-gebied, wel of geen agrarisch natuurbeheer. Dit geeft inzicht in welke gebieden het meest bijdragen aan het behalen van VHR- en N2000-doelen, en de effectiviteit van agrarisch natuurbeheer.

\section{Nieuwe natuur}

Daarnaast wordt de wens geuit om de natuur in nieuwe natuurgebieden te kunnen monitoren en onderscheid te kunnen maken tussen nieuwe natuur en bestaande natuur. Ten eerste om de (kwaliteits)ontwikkeling van het nieuwe natuurgebied goed te kunnen monitoren en ten tweede omdat kwaliteitsbeoordelingen van nieuwe en reeds bestaande natuur samen weliswaar resulteren in een hoger natuurareaal, maar veelal ook kunnen resulteren in een lagere gemiddelde natuurkwaliteit, totdat de nieuwe natuur voldoende ontwikkeld is. Het NEM dekt deze nieuwe gebieden niet, en de WMBN wordt als te uitgebreid ervaren in de pioniersfase van de nieuwe natuur. Via de LPI kan wel een toename in de soortverspreiding worden meegenomen vanuit losse waarnemingen in nieuwe natuurgebieden; dit omvat geen populatieaantallen. Eén provincie geeft aan dat nieuwe gebieden met hun standaardmonitoring worden meegenomen, ze ervaren daarbij inderdaad bij beide genoemde punten een probleem. Een andere provincie vult deze leemte in met een gebiedsschouw, een beperkte 
inventarisatie in de pioniersfase van nieuwe natuurgebieden, waarbij met referentiegebieden wordt vergeleken om te kijken hoe het nieuwe natuurgebied zich ontwikkelt.

\section{Biodiversiteit \& staat van instandhouding internationaal belangrijke soorten}

Eén provincie geeft specifiek aan dat het voor de provincie interessant is om te weten in hoeverre internationaal belangrijke soorten gedekt worden door de N2000-gebieden en in hoeverre extra gebieden nodig zijn voor een goede staat van instandhouding van deze soorten. Worden hiervoor de goede instrumenten ingezet, hebben deze het gewenste effect en hoe past de monitoring hierbij?

\section{Referenties}

Er wordt verschillend gedacht over het weergeven van natuurkwaliteit ten opzichte van een ecologische referentie (relatief intact systeem). Uit politieke overwegingen kiest een provincie ervoor om natuurkwaliteit alleen relatief aan te geven ten opzichte van een beleidsrelevant jaar, in plaats van ten opzichte van een ecologische referentie. Er is ervaren dat de ecologische referenties in twijfel zijn getrokken. Een andere provincie geeft juist aan de kwaliteit te willen zien in relatie tot een ecologische referentie, om zo expliciet te maken wat er in de provincie aan natuurkwaliteit resteert, mede als onderbouwing van inspanningen voor natuur op de provinciale politieke agenda.

\subsubsection{Databehoefte}

\section{Informatiebehoefte}

\section{Provinciedekkende informatie}

Alle vier provincies geven aan dat ze behoefte hebben aan informatie die de gehele provincie dekt. Dit betreft:

- Alle ecosystemen, dus ook agrarische en stedelijke milieus, met onderscheid naar beleidstype (zie paragraaf 2.3.2.);

- Soortdata over alle ecosystemen, dus bijvoorbeeld van VHR-soorten ook het voorkomen buiten VHRgebieden.

\section{Frequentie}

Voor enkele indicatoren (trend natuurkwaliteit) is de gewenste rapportagefrequentie elk jaar. Voor andere indicatoren wordt een minimale frequentie van een keer per vier jaar genoemd, om zo aan te kunnen sluiten bij de collegeperiodes.

Aggregatie \& afstemming

Eén provincie geeft aan dat ze behoefte hebben om de WMBN-data te aggregeren: hoe kan je de set aan gegevens het beste gebruiken voor 1 ) het informeren van bestuurders, 2) bijstellen van het beleid en 3 ) informeren van natuurbeheerders?

Eén provincie geeft aan behoefte te hebben aan eenduidigheid in indicatoruitkomsten. Als voorbeeld wordt genoemd: als gebieden met veel Rode Lijst-soorten ook een hoge kwaliteitsbeoordeling in SNL hebben, dan wijzen beide indicatorresultaten dezelfde, positieve, kant op. De provincie vraagt zich daarnaast af of in dit voorbeeld deze informatie wel uit het WMBN kan volgen; immers, voor de Rode Lijst worden deels andere soorten gemonitord dan voor de WMBN. De provincie geeft aan behoefte te hebben aan monitoring van meer soorten dan de WMBN-soorten.

Kosten

Eén provincie geeft aan geïnteresseerd te zijn in de monitoringskosten per soort en vegetatietype (Beheertype dan wel Habitattype).

\section{Informatievoorziening}

Aanvullingen op bestaande monitoring

De hierboven beschreven informatiebehoefte vraagt aanvullende monitoring in of naast de bestaande meetnetten NEM, WMBN en SDF's. Deze aanvulling is gewenst op zowel ecosysteemniveau (het agrarisch en stedelijk gebied en natuur buiten het NNN) als op soortniveau (bijvoorbeeld monitoring 
van VHR-soorten ook buiten de VHR-gebieden). Daarnaast is behoefte aan een hogere informatiedichtheid, zowel ten aanzien van ruimtelijke dekking (meer monitoringspunten voor provinciale toepassingen) als temporele dekking (jaarlijkse monitoring om trends op jaarbasis te kunnen actualiseren). Eén provincie geeft specifiek aan dat de monitoring in WMBN hier ontoereikend voor is. Als aandachtspunt voor de WMBN wordt ook genoemd de intensieve, maar selectieve monitoring, waardoor in het NNN door beheerders en/of provincies niet of nauwelijks op andere faunagroepen gemonitord wordt.

De huidige monitoringssystemen dekken deze informatiebehoeften niet structureel. Op enkele vlakken bestaan al wel andere monitoringssystemen, denk aan het stadsvogelmeetnet MUS van SOVON. Voor andere soortgroepen en gebieden moet naar andere databronnen worden gekeken. Naast de bestaande meetnetten kan gedacht worden aan aanvullende data uit NDFF (citizen science), zoals in de LPI wordt opgenomen, gericht op soortverspreiding.

Overigens zal het altijd kunnen voorkomen dat indicatorresultaten verschillende richtingen op wijzen. Immers, elke indicator beoordeelt een specifiek onderdeel van natuur, en indicatorresultaten moeten dan ook worden geïnterpreteerd in het licht van het doel waarvoor de indicator is ontwikkeld en de wijze waarop deze is samengesteld. Verschillende indicatoren met ogenschijnlijk verschillende resultaten kunnen dan allebei correct zijn ten opzichte van hun eigen doel. Ze kunnen daarmee ook juist inzicht geven in onderliggende factoren in de ontwikkeling van natuurkwaliteit. Het volledigste beeld van natuurkwaliteit wordt dan ook verkregen door de indicatoren in samenhang te bekijken; ze zijn vaak complementair aan elkaar.

\section{Provinciale monitoring}

Algemeen geven de vier provincies aan dat rond de jaren zeventig provinciale meetnetten voor flora en fauna bestonden. In de daaropvolgende decennia zijn deze veelal wegbezuinigd. In de praktijk betekent dit dat deze data moeilijk of niet gebruikt kunnen worden voor indicatoren die trends op jaarbasis weergeven. Trends over lange perioden kunnen wel weergegeven worden, hoewel soms met de nodige moeite (verschillen in soortensets, gebieden etc.).

Enkele provincies hebben de monitoring wel zelf voortgezet. Zo monitort een provincie zelf in een cyclus van tien jaar het gehele gebied buiten NNN, omdat het NEM-meetnet hier niet in voorziet. Voor deze provincie mag het NEM-meetnet verdicht worden; het LMF-meetnet hebben ze zelf verdicht. Een andere provincie heeft in een nieuw provinciaal monitoringsplan ook het monitoren voor het agrarisch natuurbeheer benoemd ${ }^{1}$. Inhoudelijk aandachtspunt hier is dat de kerngebieden niet permanent op dezelfde locatie liggen.

\footnotetext{
${ }^{1}$ BIJ12 en SOVON werken inmiddels een plan uit om dit in alle provincies in te zetten.
} 


\section{Samenhang indicatoren}

\subsection{Relatie indicatoren en beleidsdoelen}

Strikt genomen heeft het rijk slechts één indicator in zijn begroting opgenomen, namelijk de Rode Lijst Index. Deze indicator is op dit moment alleen op landelijk niveau uitgewerkt. Omdat de Rode Lijsten op landelijk niveau zijn opgesteld, is uitwerking op provinciaal niveau niet eenvoudig te realiseren. Zoals aangegeven in paragraaf 2.3.1 stelt het internationale natuurbeleid weliswaar randvoorwaarden aan indicatoren, maar omvat het geen verplichting voor toepassing van een specifieke indicator, behalve voor de VHR. Dit impliceert dat provincies hun eigen keuzes kunnen maken ten aanzien van indicatoren. Twee aandachtspunten hierbij zijn: 1) afstemming in indicatoren tussen provincies onderling en tussen provincies en rijk levert een eenduidiger overzicht en 2) afstemming van het bijbehorende monitoringsprogramma voorkomt dubbele inspanningen. In de praktijk zien we dit terugkomen in het overleg tussen rijk en provincies én tussen provincies onderling, bijvoorbeeld in het kader van het Natuurpact. Deze punten komen ook tot uiting in bijvoorbeeld de belangstelling van de provincies voor provinciale uitwerking van VHR-indicatoren.

Ook zonder momenteel door het rijk voorgeschreven provinciale indicatoren is meer inzicht te geven in de relatie tussen de indicatoren uit hoofdstuk 2 en de beleidsdoelen. De meeste indicatoren die momenteel voor het terrestrische natuurbeleid ontwikkeld zijn, hebben betrekking op het CBD-, VHRen NNN-beleid (zie paragraaf 2.1). De provinciale indicatoren die momenteel gebruikt worden, zijn meestal gericht op de het bredere biodiversiteitsbeleid, CBD-gerelateerd (zie paragraaf 2.2). In Figuur 2 worden de besproken indicatoren onder het natuurbeleid geplaatst en is weergegeven hoe informatiestromen lopen vanuit verschillende monitoringsbronnen (monitoring wordt verder toegelicht in paragraaf 3.2).

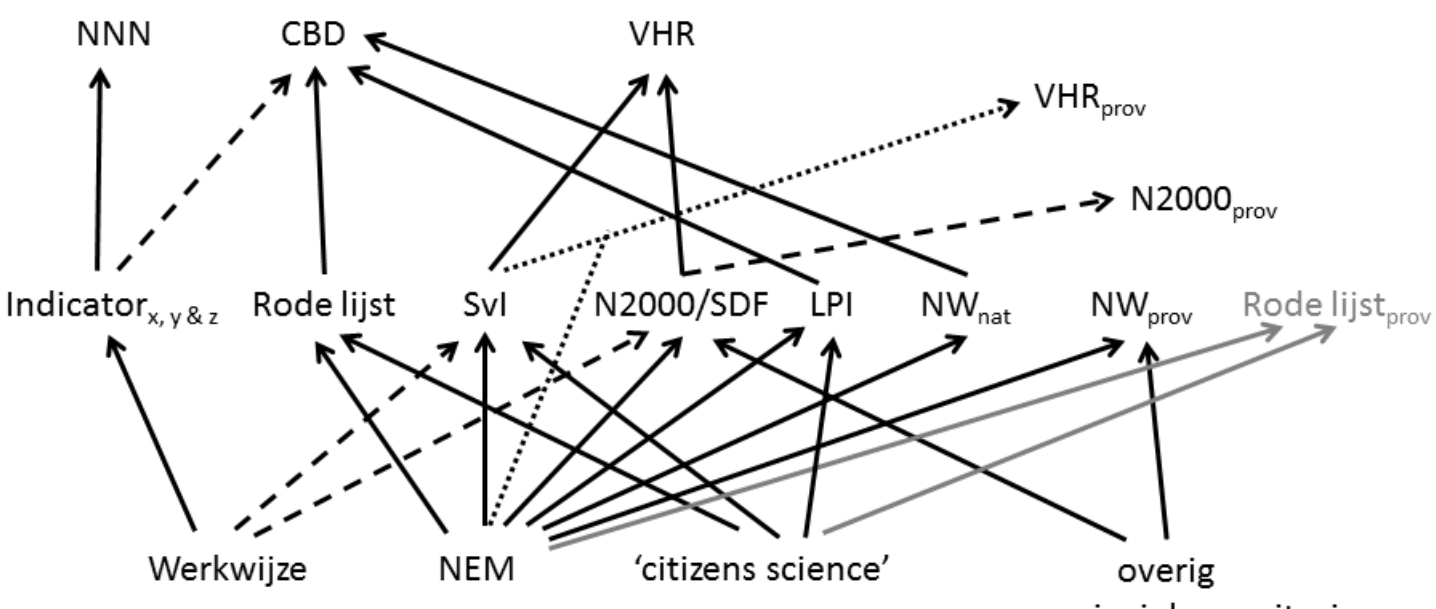

o.a. provinciale monitoring

Figuur 2 Schematische weergave van informatiestromen vanuit monitoringsgegevens (onderste rij) naar (een groep van) indicatoren op nationale en provinciale schaal (middelste rij) naar natuurbeleid (bovenste rij). Met een groep van indicatoren wordt bedoeld dat één indicator, bijvoorbeeld de SvI (Staat van Instandhouding) van soorten, is opgebouwd uit meerdere indicatoren, zoals populatiegrootte, kwaliteit leefgebied en verspreiding. Dichte lijnen betreffen informatiestromen die momenteel al functioneren en onderbroken lijnen betreffen informatiestromen die in de toekomst mogelijk nieuwe indicatoren kunnen voeden. De informatiestroom naar VHR prov is gestippeld weergegeven, omdat niet duidelijk is of de informatiestroom via de nationale indicator loopt of ontwikkeld moet worden vanuit de basisgegevens. Voor de N2000-indicator loopt de informatiestroom via op nationale schaal verzamelde gegevens (Bink et al. 2015). De Rode Lijst indicator op provinciaal niveau is in grijs weergegeven, omdat de huidige indicator niet meer operationeel is. 


\subsection{Relatie indicatoren en monitoring}

Om te beoordelen wat de status en trend zijn van de betreffende soorten, ecosystemen en condities, wordt gebruikgemaakt van meerdere databronnen (zie ook Figuur 2). De databronnen verschillen van elkaar op een aantal vlakken. Dit heeft effect op hun toepassingsmogelijkheden voor ander natuurbeleid dan waarvoor de monitoringssystemen zijn opgezet. De belangrijkste verschillen zijn: meetdoel, ruimtelijke dekking, meetfrequentie en soort-/vegetatietypeselectie.

\section{Meetnetten}

Het NEM-meetnet is opgezet om informatie over natuurkwaliteit op landelijk niveau te kunnen genereren. Hiervoor worden steekproefsgewijs, op eenmalig selecteerde locaties, jaarlijks soorten uit diverse flora- en faunasoortgroepen gemonitord volgens vastomlijnde protocollen zoals LMF (flora), BMP (broedvogels). Voor de NEM-meetdoelen wordt in toenemende mate gebruik gemaakt van andere dataverzamelingen die grotendeels bijeengebracht zijn in de NDFF. Hieronder vallen bijvoorbeeld monitoringsdata vanuit WMBN.

De WMBN is opgezet om zesjaarlijks op natuurgebiedsniveau te kunnen rapporteren over natuurkwaliteit, waarbij de gegevens ook op landelijk niveau worden geaggregeerd. De monitoring omvat zo mogelijk vlakdekkende inventarisatie van vegetatie, flora en fauna (Schmidt et al. 2015). De dataverzameling van flora en fauna vanuit de WMBN kenmerkt zich daarmee door een hogere dichtheid aan waarnemingen en veelal een lagere frequentie dan de steekproefsgewijze opnamen volgens de monitoringprotocollen uit het NEM. De WMBN omvat daarnaast ook monitoring van abiotische en ruimtelijke condities. Abiotiek wordt nog niet systematisch gemonitord, abiotische situaties worden indirect bepaald aan de hand van vegetatieopnamen. Directe monitoring van abiotiek is aan te bevelen. In de WMBN wordt monitoring voor NNN en Natura2000/PAS op elkaar afgestemd.

'Citizen science' ${ }^{2}$ is de term die wordt gebruikt voor soortdata die individuele waarnemers doorgeven op openbare websites als waarneming. $\mathrm{nl}$ of telmee.nl. Deze gegevens worden gecheckt en ingevoerd in de NDFF-database. Karakteristiek aan deze data is een sterk waarnemerseffect, met typisch meer waarnemingen van aantrekkelijke of aparte soorten dan van meer gewone soorten, veel meldingen van eenzelfde opvallende groep (groepen kraanvogels bijvoorbeeld) en een voorkeur voor mooie locaties. De checks van het NDFF richten zich er onder meer op hieruit de reële data te destilleren. Omdat niet op gestandaardiseerde wijze wordt gemonitord, worden deze data vaak meegenomen als verspreidingsdata en niet als aantalsdata.

Provinciale monitoring kan vele aspecten beslaan. Veelal valt hieronder een provinciale verdichting van het florameetnet LMF. Andere provinciale monitoring omvat weidevogelmonitoring en soms provinciedekkende faunamonitoring, maar dan minder frequent, bijvoorbeeld een keer in de tien jaar.

\section{Indicatoren en meetnetten}

De hierboven genoemde datasets zijn veelal specifiek ontwikkeld ten behoeve van een indicator. De meest gebruikte combinaties staan weergegeven in Figuur 2. Toepassing van een dataset voor een andere indicator vraagt vaak aanpassingen aan hetzij de monitoring, hetzij de indicator.

Zo heeft de indicator Natuurwaarde voor provinciale toepassing aanvullende soortdata nodig en een jaarlijkse monitoring van soortaantallen volgens vastgesteld protocol. In andere datasets wordt niet structureel jaarlijks gemeten (WMBN minimaal $1 *$ per 6 jaar, meeste provinciale monitoring tot $1 *$ per 10 jaar), worden andere meeteenheden gebruikt (provinciale monitoring per $10 * 10 \mathrm{~km}$-hok in plaats van per steekproefpunt) of wordt niet gestructureerd gemonitord. Deze datasets zijn wel geschikt om verspreidingsgegevens te genereren (citizen science).

\footnotetext{
2 Naast 'citizen science' is ook de term 'big data' bekend. Citizen science betreft onderzoekstaken zoals observaties die uitgevoerd worden door vrijwilligers die niet noodzakelijk wetenschappers zijn; hier wordt vaak de nadruk gelegd op de verzamelwijze. Big data betreffen meer de grote hoeveelheid en diversiteit van datasets; hierbij ligt vaak de nadruk op de data-analyse, waarbij uit enorme datasets getracht wordt nieuwe relaties te herleiden. Voor natuurdata zoals op waarneming. $\mathrm{nl}$ en telmee. $\mathrm{nl}$ wordt nu meestal de term citizen science gehanteerd.
} 
De NNN-indicatoren hebben een specifieke monitoringinformatie op beheertypeniveau nodig. Hiervoor zijn de NEM-data ontoereikend, deze zijn landelijk steekproefsgewijs opgezet en geven geen betrouwbare informatie op gebiedsniveau.

Mogelijkheden voor aanvullend gebruik van data staan in de grafiek weergegeven: zo gebruikt LPI zowel data uit het NEM als citizen science en gebruikt de Natuurwaarde provinciaal zowel NEM-data als provinciale data. Voor andere mogelijkheden is nog actie nodig. Concreet gebruik van WMBN-data voor EU-rapportages vraagt bijvoorbeeld nog verdere afstemming van de soortensets (Schmidt et al. 2015). WMBN-data dragen wel veel bij aan de habitatinformatie.

Waar afstemming van soortenlijsten een zinnige optie kan zijn om meervoudig datagebruik mogelijk te maken, blijft het verschil in enerzijds meetfrequentie en anderzijds meetdichtheid en protocol nog (te) groot om wederzijds meer gebruik van elkaars data mogelijk te maken.

\subsection{Complementariteit in indicatorresultaten}

Elke indicator geeft zijn eigen specifieke informatie, gebaseerd op specifieke data. Dit hangt deels samen met de vraag (beleidsdoel) en deels met (ontwikkelingen in) het aanbod van data. De verschillende indicatoren belichten zo elk een onderdeel van het brede spectrum van natuurkwaliteit.

Op het eerste gezicht kan het lastig worden als verschillende indicatoren verschillende signalen af lijken te geven. Vaak echter is dit enkel een gevolg van de verschillen in referenties, selecties van soorten/vegetatietypen, de ruimtelijke dekking en meetfrequentie. Zo kan het zijn dat een indicator voor kwaliteit van de natuur in het stedelijk gebied toeneemt; dit wordt dan vooral zichtbaar bij een CBD-indicator en niet bij een NNN-indicator, omdat de CBD-indicator een bredere soortselectie heeft. Ook is het mogelijk dat specifieke acties ten gunste van VHR-doelen ertoe leiden dat indicatoren voor het VHR-beleid een ander beeld geven dan indicatoren die ook algemene soorten in ogenschouw nemen. En als laatste voorbeeld kan een LPI-indicator met meer algemene soorten en zonder ecologische referentie een stijgende lijn laten zien, terwijl een Natuurwaarde-indicator met kenmerkende ecosysteemsoorten met ecologische referentie een licht dalende lijn laat zien.

Van groot belang is dus altijd de indicatorresultaten te voorzien van precieze toelichting over het doel van de indicator en relevante keuzes in de genoemde indicatorkenmerken (o.a. referentie, soortselectie, ruimtelijke dekking en meetfrequentie). Schijnbaar tegenstrijdige resultaten moeten daarmee uitlegbaar zijn, zodat geen onduidelijkheden overblijven wanneer meerdere resultaten gezamenlijk een beeld van de natuurkwaliteit geven. Blijven er onverklaarde verschillen over, dan mag de ontwikkelaars gevraagd worden hun indicatoren aanvullend toe te lichten.

Daarnaast is het verstandig de indicatorresultaten in het bredere perspectief van natuurkwaliteit in Nederland of Europa te plaatsen voor beter inzicht in de zeggingskracht van de specifieke indicatorresultaten. Dit kan ook betekenen dat meer dan een grafiek wenselijk is om de verschillende aspecten goed te belichten.

Een aandachtspunt bij complementariteit is ook het aggregeren van provinciale indicatorresultaten tot één landelijk beeld. Bij provinciale uitwerking wordt vaak gekozen voor een provinciaal relevante insteek i.p.v. een landelijke; dit geeft een verschil in de grondslag voor berekening. Een voorbeeld is een indicator waarvoor soorten van belang zijn: voor provinciale uitwerking van zo'n indicator wordt vaak enigszins afgeweken van de landelijke soortselectie, om beter aan te sluiten bij specifieke soorten voor de provincie. Dit resulteert in inconsistente grondslagen, waardoor de provinciale resultaten niet direct onderling vergeleken noch direct geaggregeerd kunnen worden. Voor beide is dan teruggrijpen naar de provinciale data nodig en vervolgens het berekenen van de landelijke situatie en, waar gewenst, het berekenen van de provinciale situaties t.o.v. dezelfde landelijke grondslag. Voorafgaand aan provinciaal en landelijk gebruik van een graadmeter is het daarmee belangrijk duidelijke afspraken te maken over doelen en data. 


\section{$4 \quad$ Conclusies en aandachtspunten}

Op basis van de gehouden interviews in vier provincies en literatuurstudie kunnen de volgende conclusies worden getrokken:

1. Op nationaal schaalniveau worden meerdere indicatoren voor natuurkwaliteit gebruikt; deze zijn onder te verdelen in drie hoofdthema's: soorten, ecosystemen en condities/knelpunten. Een deel van deze indicatoren is toegespitst op specifiek natuurbeleid, andere zijn ontwikkeld voor algemene evaluaties van de natuur. Op provinciaal niveau wordt deels gebruikgemaakt van deze nationale indicatoren, aangepast voor provinciaal gebruik, en deels van provinciaal ontwikkelde indicatoren. Ontwikkeling van provinciale indicatoren vraagt overigens goede afspraken vooraf over doelen en data, omdat bij provinciale uitwerking vaak gekozen wordt voor een provinciaal relevante insteek i.p.v. een landelijke, wat een verschil geeft in de grondslag voor berekening. Dit is een aandachtspunt bij aggregatie van provinciale indicatorresultaten tot landelijke resultaten.

2. Wensen van de provincies ten aanzien van indicatoren voor natuurkwaliteit zijn met name:

a. Provinciedekkende indicatoren

i. Ecosystemen: naast de natuurgebieden en reguliere ecosystemen ook informatie over agrarisch en stedelijk gebied en grote wateren;

ii. Soorten: provinciedekkende soortenmonitoring.

b. Provinciale informatie: landelijke informatie die uit provinciale natuurgebieden komt ook provinciaal beschikbaar krijgen (VHR).

c. Provinciale Rode Lijst indicator; enkele provincies zijn hierin geïnteresseerd om de trends te bepalen en frequentere informatie te hebben; andere provincies delen deze wens niet, omdat ze sturen op NNN-soorten in plaats van Rode Lijst-soorten.

Aandachtspunt hierbij is dat de vier provincies niet noodzakelijk de wensen van alle provincies weerspiegelen.

3. Beschikbare monitoringsgegevens zijn gedeeltelijk provinciaal toepasbaar:

a. Wel toepasbaar voor de indicatoren die:

i. de provincies zelf weergeven o.b.v. hun eigen monitoring;

ii. gebaseerd zijn op gebiedsgegevens, zoals VR- en HR-rapportages en waarschijnlijk NNNrapportages.

b. Niet toepasbaar voor de provinciale wens voor provinciedekkende informatie en voor uitwerking van landelijke indicatoren. Daarvoor wordt gemist:

i. Monitoring van agrarisch en stedelijk gebied en grote wateren; meetnet MUS en agrarisch gebied zijn hiervoor al beschikbaar, maar vragen nog uitgebreidere dekking;

ii. Verdichting van het meetnet voor de huidige ecosystemen zodat dit toereikend is voor betrouwbare resultaten op provinciaal niveau;

iii. Uitwerking van het conceptuele kader voor provinciale toepassing van enkele landelijke indicatoren: Rode Lijst - soortselecties, Natuurwaarde - soortreferenties;

iv. Meetfrequentie van sommige monitoringsgegevens vaak zesjaarlijks, terwijl jaarlijks of vierjaarlijks informatie beschikbaar moet zijn voor goede trendanalyses (statistisch vereiste).

4. De samenhang tussen de indicatoren en complementariteit in beoordelingen:

a. Provincies gebruiken de indicatoren die zij zelf relevant vinden voor hun natuurbeleid; vanuit het rijk wordt - nog - niet expliciet om bepaalde indicatoren gevraagd. Het rijk moet zelf wel informatie aan de EU leveren, hierbij is echter geen specifieke indicator voorgeschreven. In toenemende mate wordt wel al aandacht besteed aan de afstemming van indicatoren, zowel tussen provincies onderling als tussen provincies en rijk, zoals in het kader van de Voortgangsrapportage Natuur. 
b. De huidige set aan indicatoren levert een brede kijk op de natuurkwaliteit op provinciaal en landelijk niveau. Deze brede kijk is noodzakelijk om meerdere aspecten van natuurkwaliteit te kunnen blijven volgen.

c. Aggregatie van de indicatoren onderling (bijvoorbeeld Natuurwaarde landelijk afleiden uit NNN-indicatoren) is vooralsnog niet haalbaar; hiervoor verschillen zowel de doelen, de referenties als de monitoringssystemen nog te veel van elkaar.

d. Integratie van provinciale indicatoren tot nationale indicatoren wordt bemoeilijkt als provincies verschillend invulling geven aan indicatoren, bijvoorbeeld door verschillen in monitoringsprotocol en temporele dekking. Ook hieraan wordt in toenemende mate aandacht geschonken in interprovinciale afstemming.

e. Ogenschijnlijk verschillende indicatorresultaten zullen bijna altijd optreden, maar hoeven geen probleem te vormen zolang het indicatordoel en de relevante samenstelling helder weergegeven worden bij het indicatorresultaat. Een plaatje alleen is dus nooit genoeg.

f. Aanvullend is dan wel een analyse van de oorzaken van verschillen in resultaten nodig, dit kan ook leiden tot meer inzicht in de ecologische processen die plaatsvinden.

Hieruit kunnen we de volgende aanbevelingen herleiden:

1. Blijvende afstemming: het lijkt onmogelijk om in één stap tot een samenhangend monitoringssysteem te komen dat voor alle doelen en schaalniveaus geschikt is. Daarnaast leert de ervaring dat monitoringssystemen onderhevig kunnen zijn aan veranderingen. Het is daarom van groot belang dat er afstemming blijft plaatsvinden tussen provincies onderling en tussen rijk en provincies met betrekking tot gebruikte indicatoren en meetnetten. Belangrijk blijft voldoende spreiding in type indicatoren, op hoofdlijnen trendindicatoren en verklarende indicatoren, met bijpassende meetnetten.

2. Nieuwe indicatoren: alle provincies geven aan dat indicatoren gewenst zijn voor agrarisch en stedelijk gebied. Aangezien deze indicatoren momenteel nog ontwikkeld moeten worden, is afstemming in een vroege fase wenselijk. Het risico bestaat dat er verschillen gaan ontstaan in de uitwerking, waardoor verschillende provincies verschillende soortensets, referentiewaarden of monitoringsgegevens gebruiken. Aggregatie tot een landelijke indicator voor het agrarische of stedelijke gebied is dan lastig. Tevens zijn aanpassingen van indicatoren niet wenselijk als ze reeds enkele jaren gebruikt zijn om provinciaal en rijksbestuur te informeren.

3. Provinciale uitwerkingen van landelijke indicatoren: momenteel zijn er nog enkele verschillen in toepassingen van landelijke indicatoren op provinciaal niveau. Het belangrijkste verschil heeft betrekking op gekozen referenties. Om te komen tot een indicator die ook eenvoudig landelijk is te aggregeren, is het wenselijk om af te stemmen welke referenties er landelijk gebruikt worden en waar provincies afwijken voor hun eigen specifieke toepassing.

4. Afstemming tussen meetnetten: voor verschillende indicatoren op provinciale schaal zijn aanvullende data nodig, een dichter meetnet. Vaak kunnen gegevens uit provinciale meetnetten nationale meetnetten aanvullen. Zeker als de monitoringsprotocollen hetzelfde zijn. Op basis van deze studie zijn geen specifieke aanbevelingen te doen voor afstemming van de verschillende monitoringsprogramma's. In een vervolgonderzoek zou nagegaan kunnen worden in hoeverre het mogelijk is om landelijke dan wel provinciale meetnetten eenvoudig aan te vullen zijn, zodat ze voor meerdere toepassingen geschikt worden. Denk hierbij aan afstemming in soortensets, monitoringsprotocollen en meetfrequentie.

5. Presentatie indicator: aangezien elke indicator een specifieke weergave van de werkelijkheid is, dienen resultaten altijd voorzien te zijn van een helder onderschrift. Wat zegt deze indicator, wat is het domein en waarop is hij gebaseerd? 


\section{Literatuur}

Beek, J.G. van, R.F. van Rosmalen, B.F. van Tooren, en P.C. van der Molen (allen red.) (2014). Werkwijze Natuurmonitoring en Beoordeling Natuurnetwerk en Natura 2000/PAS (+ 2 bijlagedocumenten) BIJ12, Utrecht 2014.

BIJ12 (2014). Werkwijze Monitoring en Beoordeling Natuurnetwerk en Natura 2000/PAS. Versie 05032014. BIJ12, Utrecht.

Bink, R.J., A.J. Griffioen \& A. van Kleunen (2015 in prep). Provinciale informatie uit landelijke natuurrapportages voor de Europese Commissie (Habitatrichtlijn, Vogelrichtlijn, Standaard Data Formulieren) over de periode 2007-2012. Wageningen, Alterra Wageningen UR, Alterra-rapport.

CBS, PBL, Wageningen UR (2015). Trend fauna - alle gemeten soorten - Living Planet Index Nederland, 1990-2014 (indicator 1569, versie 02, 29 oktober 2015).

www.compendiumvoordeleefomgeving.nl. CBS, Den Haag; Planbureau voor de Leefomgeving, Den Haag/Bilthoven en Wageningen UR, Wageningen.

Greft-van Rossum, J.G.M. van der, B. de Knegt, J.Y. Frissel, R. Pouwels, M. Sanders, G.W.W. Wamelink, R.M.A. Wegman, J. Clement, P. van Puijenbroek, L.B. Sparrius en C.A.M. van Swaay (2015). Biodiversiteitsgraadmeters Noord-Holland; Status en trend van ecosystemen en soorten. Wageningen, Alterra, Alterra-rapport 2543.

IPO (2013). Natuurkwaliteit en monitoring in de EHS. Een uitgave van Interprovinciaal Overleg (IPO). Publicatienummer 305.

Knegt, B. de, J.G.M. van der Greft-van Rossum en R. Pouwels (2012). Biodiversiteitsgraadmeter ZuidHolland. Wageningen, Alterra, Alterra-rapport 2365.

Knegt, B. de, G.W.W. Wamelink, M.H.C. van Adrichem, J. Clement, P. van Puijenbroek, L.B. Sparrius en C. van Swaay (2013). Biodiversiteitsgraadmeters Fryslân; Status en trend van hoofd-natuurtypen en soorten. Wageningen, Alterra, Alterra-rapport 2431.

Reijnen, M.J.S.M., A. van Hinsberg, M.L.P. van Esbroek, B. de Knegt, R. Pouwels, S. van Tol en J. Wiertz (2010). Natuurwaarde 2.0 land. Graadmeter natuurkwaliteit land ecosystemen voor nationale beleidsdoelen. Wageningen, Wettelijke Onderzoekstaken Natuur \& Milieu, WOt-rapport110.

Schmidt, A.M. en Knegt, B. de (2014). Van internationaal naar provinciaal natuurbeleid; De doorwerking van internationale afspraken over behoud en herstel biodiversiteit naar de provincies. Wageningen, Alterra. Alterra-rapport 2566.

Schmidt, A.M., R.J. Bijlsma, L. Soldaat, C.A.M. van Turnhout, C.A.M. van Swaay, D. Zoetebier en I. Woltjer (2015). Naar een samenhangend monitoring- en beoordelingssysteem voor het natuurbeleid; Deel I. Evaluatie van de bruikbaarheid van gegevens van de Werkwijze Monitoring en Beoordeling Natuurnetwerk en Natura 2000/PAS voor de Europese rapportages. Wageningen, Alterra, Alterra-rapport 2645. 


\section{Bijlage 1 Overzicht indicatoren}

Het overzicht is opgesplitst in indicatoren voor soorten, ecosystemen, condities en gebieden. Deze laatste categorie bevat op gebiedsniveau indicatoren voor soorten, ecosystemen en condities. In het overzicht zijn per indicator enkele aspecten kort uitgewerkt. Tevens is aangegeven of provincies aan hebben gegeven deze indicator in de toekomst mogelijk te willen gebruiken.

\begin{tabular}{|c|c|c|c|c|}
\hline Indicator & Rode Lijst Indicator & LPI (Occupancy modelling) & HR-soorten SvI & VR-soorten SVI \\
\hline Doel & CBD & CBD & VHR & VHR \\
\hline Figuur & 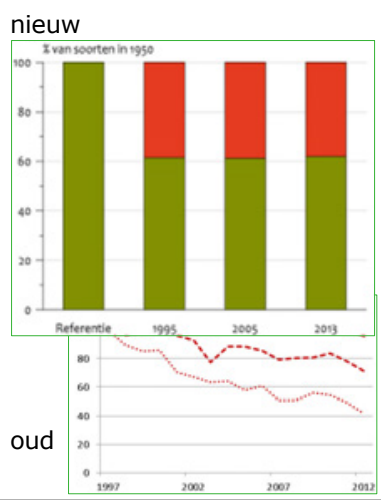 & \begin{tabular}{|l|l|} 
steenrode heidelibel / trend 2005 -2013 \\
toename \\
stabiel \\
ofname \\
onzeker \\
te weinig data
\end{tabular} & 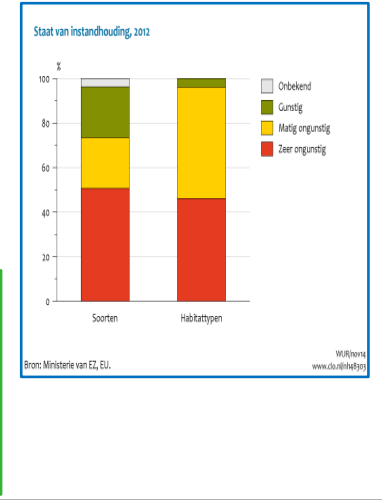 & 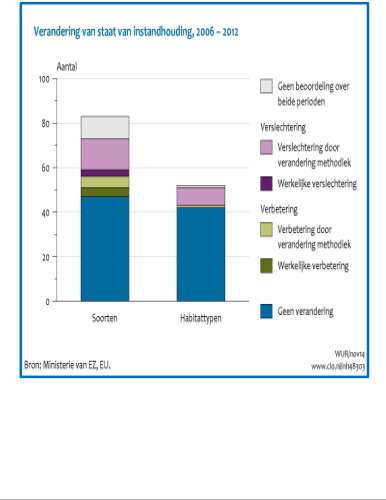 \\
\hline Omschrijving & $\begin{array}{l}\text { Nieuw: Verandering in aantal } \\
\text { soorten en de mate van } \\
\text { bedreiging op de Rode Lijst } \\
\text { van } 7 \text { soortgroepen. } \\
\text { Oud: Verandering in populaties } \\
\text { van soorten (alle, Rode Lijst } \\
\text { en bedreigde soorten van } \\
\text { Rode Lijst). }\end{array}$ & $\begin{array}{l}\text { Trends in verspreiding van } \\
\text { soorten; bij voldoende data } \\
\text { ook in populatieomvang en per } \\
\text { provincie }\end{array}$ & $\begin{array}{l}\text { Trend in Staat van } \\
\text { Instandhouding of deelaspect } \\
\text { (verspreiding, populatie, } \\
\text { leefgebied en/of } \\
\text { toekomstperspectief }\end{array}$ & $\begin{array}{l}\text { Trend in Staat van } \\
\text { Instandhouding of deelaspect } \\
\text { (verspreiding, populatie, } \\
\text { leefgebied en/of } \\
\text { toekomstperspectief }\end{array}$ \\
\hline $\begin{array}{l}\text { Ruimtelijke } \\
\text { dekking }\end{array}$ & $\begin{array}{l}\text { Vooral alle natuurtypen, } \\
\text { agrarisch gebied (weidevogels) } \\
\text { Gedeeltelijk akkerland en } \\
\text { stedelijk gebied }\end{array}$ & $\begin{array}{l}\text { Volledig terrestrische } \\
\text { dekking }\end{array}$ & Volledige terrestrische dekking & Volledige terrestrische dekking \\
\hline Data & NEM, NDFF & NEM \& NDFF & NEM, NDFF & NEM, NDFF \\
\hline Frequentie & $\begin{array}{l}\text { Jaarlijkse update data o.b.v. } \\
\text { (meer)jaarlijkse monitoring }\end{array}$ & $\begin{array}{l}\text { Jaarlijkse update data o.b.v. } \\
\text { (meer)jaarlijkse monitoring }\end{array}$ & 6-jaarlijks & 6-jaarlijks \\
\hline $\begin{array}{l}\text { Provinciale } \\
\text { uitwerking }\end{array}$ & $\begin{array}{l}\text { Nee; uitwerking op provinciaal } \\
\text { niveau wordt onderzocht. } \\
\text { Oude methode wel uitgewerkt, } \\
\text { maar wordt niet meer } \\
\text { gebruikt. }\end{array}$ & $\mathrm{Ja}$ & Nee & Nee \\
\hline $\begin{array}{l}\text { Genoemd bij } \\
\text { provincies }\end{array}$ & Ja, graag ook provinciaal & $\begin{array}{l}\text { Ja, graag ook provinciaal en } \\
\text { per ecosysteem }\end{array}$ & Ja, hoge prioriteit & Ja, hoge prioriteit \\
\hline Opmerking & & & $\begin{array}{l}\text { geen provinciale doelen; } \\
\text { frequentie van } 6 \text { jaar te laag }\end{array}$ & $\begin{array}{l}\text { geen provinciale doelen; } \\
\text { frequentie van } 6 \text { jaar te laag }\end{array}$ \\
\hline $\begin{array}{l}\text { Karakteristie- } \\
\text { ken }\end{array}$ & $\begin{array}{l}\text { Nieuw: aantal soorten op RL; } \\
\text { oud: populatieomvang van } \\
\text { soorten op RL }\end{array}$ & $\begin{array}{l}\text { Combinatie van } \\
\text { verspreidingsdata en } \\
\text { populatieaantallen }\end{array}$ & & \\
\hline Soorten & $\begin{array}{l}\text { Alle soorten uit faunameetnet. } \\
\text { Oud: alle, RL, RL-(ernstig) } \\
\text { bedreigd. Nieuw: Alle, RL }\end{array}$ & Zo veel mogelijk soorten & HR-soorten; Bijlage II, IV \& V & VR-soorten \\
\hline Berekening & $\begin{array}{l}\text { Oud: Soortpopulatie t.o.v. } \\
\text { 1990/1997 (afh. van data); } \\
\text { Nieuw: \% faunasoorten op RL }\end{array}$ & $\begin{array}{l}\text { Index t.o.v. start meetnet; } \\
\text { deels o.b.v. verspreiding, } \\
\text { deels o.b.v. aantallen }\end{array}$ & & \\
\hline Referentie & $\begin{array}{l}\text { RLI nieuw: } \\
\text { http://www.compendiumvoord } \\
\text { eleefomgeving.nl/indicatoren/ } \\
\underline{\text { nl1521-Rode-Lijst- }} \\
\underline{\text { Indicator.html?i=2-8 }}\end{array}$ & $\begin{array}{l}\text { http://www.compendiumvoord } \\
\text { eleefomgeving.nl/indicatoren/ } \\
\text { nl1569-Living-Planet- } \\
\underline{\text { Index.html?i=2-76 }}\end{array}$ & $\begin{array}{l}\text { http://www.compendiumvoord } \\
\text { eleefomgeving.nl/indicatoren/ } \\
\text { nl1483-Staat-van- } \\
\text { instandhouding-Natura-2000- } \\
\underline{\text { soorten.html?i=2-10 }}\end{array}$ & $\begin{array}{l}\text { http://www.compendiumvoord } \\
\text { eleefomgeving.nl/indicatoren/n } \\
\text { l1483-Staat-van- } \\
\text { instandhouding-Natura-2000- } \\
\underline{\text { soorten.html?i=2-10 }}\end{array}$ \\
\hline
\end{tabular}




\begin{tabular}{|c|c|c|c|c|}
\hline Indicator & $\begin{array}{l}\text { Natuurkwaliteit } \\
\text { Ecosystemen recente trend }\end{array}$ & $\begin{array}{l}\text { Natuurwaarde } \\
\text { Ecosystemen recent }\end{array}$ & $\begin{array}{l}\text { Natuurwaardeontwikkeling } \\
\text { sinds } 1900\end{array}$ & Habitattypen SvI \\
\hline Doel & CBD & $\mathrm{CBD}$ & CBD & VHR \\
\hline Figuur & 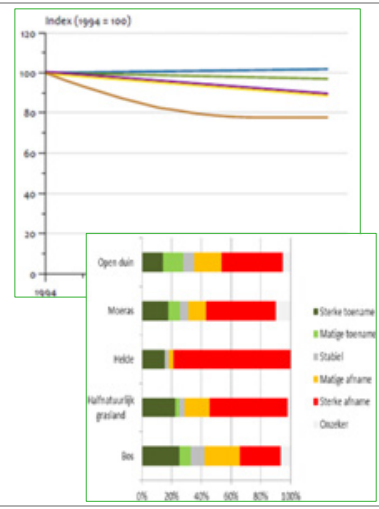 & Naturitwalitel (referenteste = 100x) & \begin{tabular}{|c|c|}
100 \\
\end{tabular} & 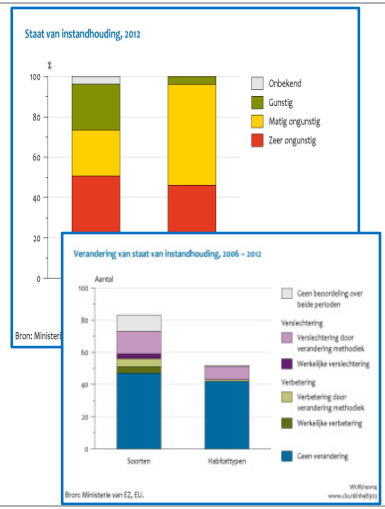 \\
\hline Omschrijving & $\begin{array}{l}\text { Jaarlijkse veranderingen in } \\
\text { natuurkwaliteit per } \\
\text { ecosysteem. }\end{array}$ & $\begin{array}{l}\text { (Verandering in) } \\
\text { natuurkwaliteit en -areaal per } \\
\text { ecosysteem voor recente } \\
\text { periode t.o.v. ongestoord. }\end{array}$ & $\begin{array}{l}\text { (Verandering in) } \\
\text { natuurkwaliteit en -areaal voor } \\
\text { recente periode t.o.v. } 1950 \text { en } \\
1900 .\end{array}$ & $\begin{array}{l}\text { Trend in Staat van } \\
\text { Instandhouding of deelaspect } \\
\text { (verspreiding, oppervlakte, } \\
\text { structuur \& functie en/of } \\
\text { toekomstperspectief) }\end{array}$ \\
\hline $\begin{array}{l}\text { Ruimtelijke } \\
\text { dekking }\end{array}$ & $\begin{array}{l}\text { Alle natuurtypen, agrarisch } \\
\text { gebied (weidevogels). } \\
\text { Niet akkerland en stedelijk } \\
\text { gebied. Uitbreidingen } \\
\text { gewenst: agrarisch met } \\
\text { flora/slootkanten; } \\
\text { provinciedekkend; onderscheid } \\
\text { nieuwe en bestaande natuur. }\end{array}$ & $\begin{array}{l}\text { Alle natuurtypen. Agrarisch } \\
\text { gebied (weidevogels) apart. } \\
\text { Niet akkerland en stedelijk } \\
\text { gebied. } \\
\text { Uitbreiding provinciedekkend } \\
\text { gewenst. }\end{array}$ & $\begin{array}{l}\text { Alle natuurtypen. } \\
\text { Niet agrarisch gebied en } \\
\text { stedelijk gebied. } \\
\text { Uitbreiding provinciedekkend } \\
\text { gewenst. }\end{array}$ & N2000 \\
\hline Data & $\begin{array}{l}\text { NEM, provinciaal aangevuld } \\
\text { met provinciale monitoring }\end{array}$ & $\begin{array}{l}\text { Natuurkwaliteit: NEM, } \\
\text { provinciaal aangevuld } \\
\text { Natuurareaal: HGN; BKN }\end{array}$ & $\begin{array}{l}\text { Natuurkwaliteit: NEM, } \\
\text { provinciaal aangevuld } \\
\text { Natuurareaal: HGN; BKN }\end{array}$ & SDF's \\
\hline Frequentie & $\begin{array}{l}\text { Jaarlijkse update data o.b.v. } \\
\text { (meer)jaarlijkse monitoring }\end{array}$ & $\begin{array}{l}\text { Jaarlijkse update data o.b.v. } \\
\text { (meer)jaarlijkse monitoring }\end{array}$ & $\begin{array}{l}\text { Jaarlijkse update data o.b.v. } \\
\text { (meer)jaarlijkse monitoring }\end{array}$ & 6-jaarlijks \\
\hline $\begin{array}{l}\text { Provinciale } \\
\text { uitwerking }\end{array}$ & $\begin{array}{l}\text { Ja; additionele data nodig; } \\
\text { soms is de aanvullende } \\
\text { provinciale monitoring uitge- } \\
\text { breid, soms niet toereikend }\end{array}$ & $\begin{array}{l}\text { Ja; additionele data nodig; } \\
\text { soms is de aanvullende } \\
\text { provinciale monitoring niet } \\
\text { toereikend }\end{array}$ & $\begin{array}{l}\text { Ja; additionele data nodig; } \\
\text { soms is de aanvullende } \\
\text { provinciale monitoring niet } \\
\text { toereikend }\end{array}$ & Nee \\
\hline $\begin{array}{l}\text { Genoemd bij } \\
\text { provincies }\end{array}$ & $\begin{array}{l}\text { Ja, graag zodanig meetnet dat } \\
\text { trendlijnen per ecosysteem } \\
\text { bepaald kunnen worden, met } \\
\text { jaarlijkse updates. } \\
\text { Een enkele provincie bepaalt } \\
\text { deze indicator zelf. }\end{array}$ & $\mathrm{Ja}$ & $\mathrm{Ja}$ & Ja, hoge prioriteit \\
\hline Opmerking & & & & $\begin{array}{l}\text { Geen doelen per provincie } \\
\text { uitgewerkt; frequentie van } \\
6 \text { jaar te laag }\end{array}$ \\
\hline $\begin{array}{l}\text { Karakteristie- } \\
\text { ken }\end{array}$ & $\begin{array}{l}\text { Per ecosysteem; op basis van } \\
\text { trends van soorten; t.o.v. } \\
1950 .\end{array}$ & Per ecosysteem; t.o.v. 1950. & $\begin{array}{l}\text { Natuur totaal, o.b.v. } 4 \\
\text { landecosystemen: bos, heide, } \\
\text { moeras en open duin (i.v.m. } \\
\text { beperkte data); expertinfo } \\
\text { voor } 1900 \text { en } 1950 .\end{array}$ & \\
\hline Soorten & $\begin{array}{l}\text { NL: Doelsoorten beleid } \\
\text { Prov: NL minus soorten die } \\
\text { niet karakteristiek zijn voor } \\
\text { Prov. }\end{array}$ & $\begin{array}{l}\text { Als boven; } 1950 \text { bevat voor } \\
\text { veel soorten data en is toch } \\
\text { relatief ongestoord; nog voor } \\
\text { de grote landinrichtingen }\end{array}$ & $\begin{array}{l}\text { Als boven voor recent en } \\
1950 ; 1900 \text { benadert meer } \\
\text { ongestoorde situatie; van } \\
\text { minder soorten referentiedata } \\
\text { bekend. }\end{array}$ & Habitattypen \\
\hline Berekening & $\begin{array}{l}\text { Soortpopulatie ten opzichte } \\
\text { van ongestoord/1950 (NL) } \\
1990 \text { (Provs); Rekenkundig } \\
\text { middelen van soorten per } \\
\text { ecosysteem }\end{array}$ & $\begin{array}{l}\text { Natuurkwaliteit * } \\
\text { nat.kwantiteit voor natuurlijke } \\
\text { terrestrische en aquatische } \\
\text { ecosystemen; als kan voor } \\
\text { agrarisch gebied }\end{array}$ & $\begin{array}{l}\text { Natuurkwaliteit * } \\
\text { nat.kwantiteit gesommeerd } \\
\text { over de ecosystemen bos, } \\
\text { heide, moeras en open duin. }\end{array}$ & \\
\hline Referentie & $\begin{array}{l}\text { http://www.compendiumvoord } \\
\text { eleefomgeving.nl/indicatoren/ } \\
\text { nl2052-Realisatie- } \\
\text { natuurdoeltypen.html?i=2-76 }\end{array}$ & $\begin{array}{l}\text { http://www.compendiumvoord } \\
\text { eleefomgeving.nl/indicatoren/ } \\
\text { nl1119-Natuurwaarde- } \\
\text { landelijk.html?i=2-76 }\end{array}$ & $\begin{array}{l}\text { http://www.compendiumvoord } \\
\text { eleefomgeving.nl/indicatoren/ } \\
\text { nl1119-Natuurwaarde- } \\
\text { landelijk.html?i=2-76 }\end{array}$ & $\begin{array}{l}\text { http://www.compendiumvoord } \\
\text { eleefomgeving.nl/indicatoren/n } \\
\text { I1483-Staat-van- } \\
\text { instandhouding-Natura-2000- } \\
\text { soorten.html?i=2-10 }\end{array}$ \\
\hline
\end{tabular}









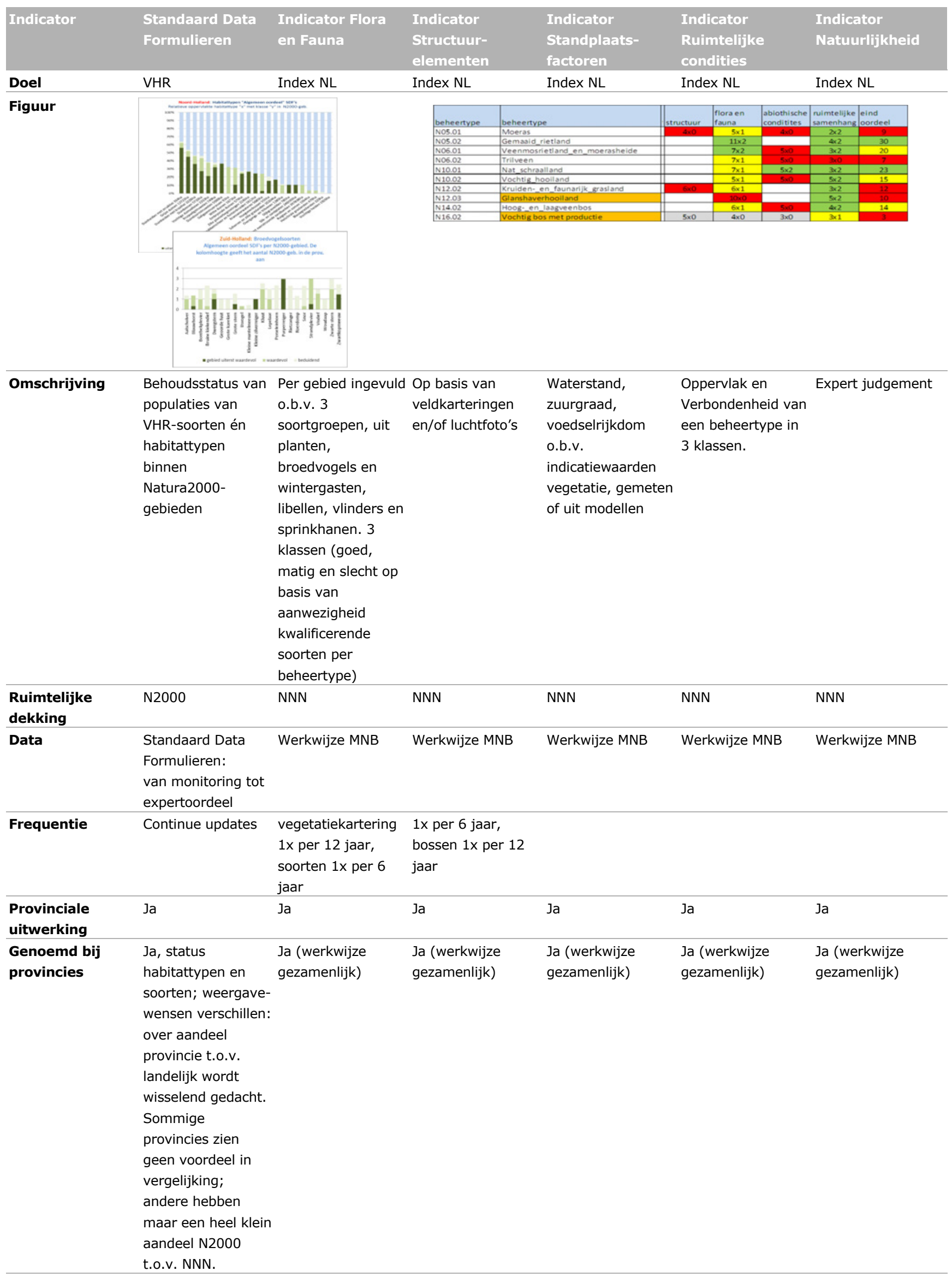

Opmerking

\section{Karakteristieken}

Soorten HR Bijlage II, VR,
Habitattypen

\section{Berekening}

Link

rapportage Ruud

Bink 


\section{Bijlage 2 Lijst van geïnterviewden}

Provincie Friesland

Meinte Engelmoer

Johan Taal

Roland Jalving

Margriet Krijn

Provincie Utrecht

Herbert Kuyvenhoven

Jandirk Kievit

Arjan Vette

Provincie Noord-Holland

Arne Distel

\section{Provincie Zuid-Holland}

Joop Kooijman

Francine van der Loop 


\section{Bijlage 3 Lijst van afkortingen}

CBD Verdrag inzake Biodiversiteit (Convention on Biological Diversity), 1992. Het verdrag kent drie hoofddoelstellingen: behoud van biologische diversiteit, het duurzaam gebruik ervan en een eerlijke verdeling van de voordelen die het gebruik van genetische bronnen opleveren.

HR Habitatrichtlijn (Habitats Directive), 1992. EU-richtlijn inzake de instandhouding van de natuurlijke habitats en de wilde flora en fauna. Het doel is bij te dragen tot het waarborgen van de biologische diversiteit in de lidstaten door bescherming van habitats en soorten die van Europees belang zijn.

N2000 Natura 2000 is een Europees netwerk van beschermde natuurgebieden. In Natura 2000gebieden worden bepaalde diersoorten en hun natuurlijke leefomgeving beschermd om de biodiversiteit te behouden. Natura 2000 is de overkoepelende naam voor gebieden die worden beschermd vanuit de Vogel- en Habitatrichtlijn.

LMF Landelijk Meetnet Flora, voluit het Landelijk Meetnet Flora - Milieu \& Natuurkwaliteit, onderdeel van het Netwerk Ecologische Monitoring (NEM). In NEM-verband zijn twee meetdoelstellingen aan het LMF opgelegd: (1) Het signaleren van landelijke veranderingen in de ecologische kwaliteit van multifunctionele gebieden; (2) Het signaleren van landelijke veranderingen in milieuaspecten, met name vermesting, verzuring en verdroging, en de gevolgen daarvan voor flora (en fauna). Bovendien moet het LMF - M\&N de informatie verzamelen betreffende de algemene plantensoorten van de landelijke natuurgraadmeters. De methode gaat uit van permanente kwadraten.

LPI Living Planet Index; indicator van de biodiversiteit gebaseerd op indexen van verspreidingsdata en populatieaantallen.

NDFF Nationale Databank Flora en Fauna, een bundeling van meer dan 100 databanken met natuurgegevens. De data komen uit zowel gestructureerde monitoring als incidentele waarnemingen en omvatten ook de PGO-databases. De data worden gevalideerd beschikbaar gesteld.

NEM Netwerk Ecologische Monitoring, het samenwerkingsverband van overheidsorganisaties voor de monitoring van de natuur in Nederland. Het doel is om de verzameling van gegevens af te stemmen op de informatiebehoefte van de overheid. Het NEM volgt de trends van vrijwel alle belangrijke soortgroepen, zoals vogels, vlinders en planten (in het LMF).

NNN Natuurnetwerk Nederland (voorheen de Ecologische Hoofdstructuur, EHS).

PGO Particuliere Gegevens verzamelende Organisatie, zoals SOVON (vogels), RAVON (reptielen, amfibieën en vissen) e.a.

SDF Standaard Dataformulier of Standaard Gegevensformulier(Standard Data Form), formulieren met ecologische gegevens over soorten en gebieden van Natura 2000.

SvI Staat van Instandhouding; betreft habitattypen en soorten van de Vogelrichtlijn en de Habitatrichtlijn. Doel is een gunstige staat van instandhouding. De ondergrens is dat er geen verslechtering mag plaatsvinden ten opzichte van de huidige situatie.

VHR Vogel- en Habitatrichtlijn, zie VR en HR afzonderlijk.

VR Vogelrichtlijn (Birds Directive), 1979. EU-richtlijn inzake het behoud van de vogelstand. Het doel is de bescherming, het beheer en de regulering van de in de lidstaten voorkomende vogels.

WMBN Werkwijze Monitoring en Beoordeling Natuurnetwerk en Natura 2000/PAS. 
Wageningen Environmental Research Postbus 47

6700 AA Wageningen

T 0317480700

www.wur.nl/environmental-research

Wageningen Environmental Research

Rapport 2750

ISSN 1566-7197
De missie van Wageningen University \& Research is 'To explore the potential of nature to improve the quality of life'. Binnen Wageningen University \& Research bundelen Wageningen University en gespecialiseerde onderzoeksinstituten van Stichting Wageningen Research hun krachten om bij te dragen aan de oplossing van belangrijke vragen in het domein van gezonde voeding en leefomgeving. Met ongeveer 30 vestigingen, 5.000 medewerkers en 10.000 studenten behoort Wageningen University \& Research wereldwijd tot de aansprekende kennisinstellingen binnen haar domein. De integrale benadering van de vraagstukken en de samenwerking tussen verschillende disciplines vormen het hart van de unieke Wageningen aanpak. 



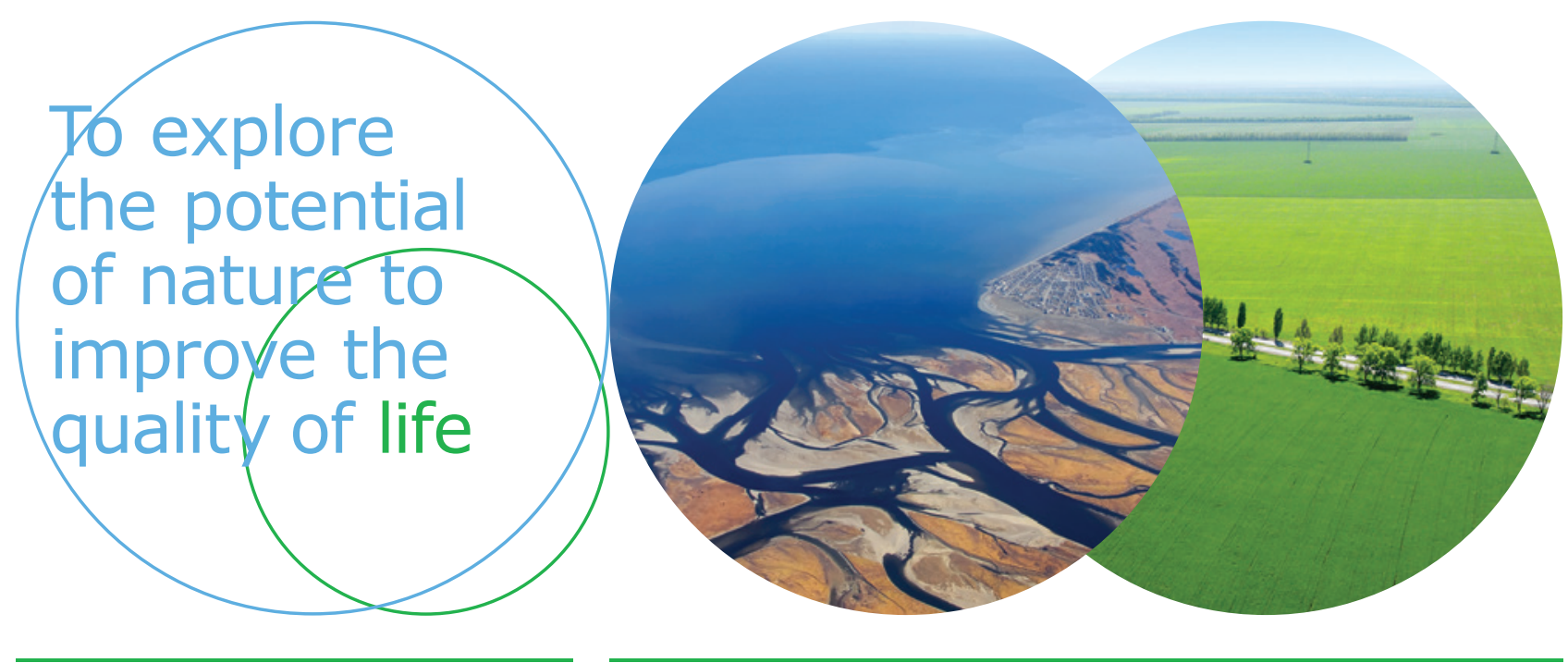

Wageningen Environmental Research Postbus 47

$6700 \mathrm{AB}$ Wageningen

T 317480700

www.wur.nl/environmental-research

Rapport 2750

ISSN 1566-7197
De missie van Wageningen University \& Research is 'To explore the potential of nature to improve the quality of life'. Binnen Wageningen University \& Research bundelen Wageningen University en gespecialiseerde onderzoeksinstituten van Stichting Wageningen Research hun krachten om bij te dragen aan de oplossing van belangrijke vragen in het domein van gezonde voeding en leefomgeving. Met ongeveer 30 vestigingen, 5.000 medewerkers en 10.000 studenten behoort Wageningen University \& Research wereldwijd tot de aansprekende kennisinstellingen binnen haar domein. De integrale benadering van de vraagstukken en de samenwerking tussen verschillende disciplines vormen het hart van de unieke Wageningen aanpak. 